\title{
Skeletal Muscle as an Endocrine Organ: The Role of Myokines in Exercise Adaptations
}

\author{
Christoph Hoffmann ${ }^{1}$ and Cora Weigert ${ }^{1,2,3}$ \\ ${ }^{1}$ Division of Pathobiochemistry and Clinical Chemistry, Department of Internal Medicine IV, University \\ Hospital Tübingen, 72076 Tübingen, Germany \\ ${ }^{2}$ Institute for Diabetes Research and Metabolic Diseases of the Helmholtz Zentrum München at the University \\ of Tübingen, 72076 Tübingen, Germany \\ ${ }^{3}$ German Center for Diabetes Research (DZD), 85764 München-Neuherberg, Germany \\ Correspondence: cora.weigert@med.uni-tuebingen.de
}

Exercise stimulates the release of proteins with autocrine, paracrine, or endocrine functions produced in skeletal muscle, termed myokines. Based on the current state of knowledge, the major physiological function of myokines is to protect the functionality and to enhance the exercise capacity of skeletal muscle. Myokines control adaptive processes in skeletal muscle by acting as paracrine regulators of fuel oxidation, hypertrophy, angiogenesis, inflammatory processes, and regulation of the extracellular matrix. Endocrine functions attributed to myokines are involved in body weight regulation, low-grade inflammation, insulin sensitivity, suppression of tumor growth, and improvement of cognitive function. Muscle-derived regulatory RNAs and metabolites, as well as the design of modified myokines, are promising novel directions for treatment of chronic diseases.

$T_{\mathrm{p}}^{\mathrm{h}}$ he importance of regular physical activity to prevent and treat chronic and degenerative diseases is widely accepted. This does not only include metabolic diseases such as type 2 diabetes and morbid obesity but most if not all widespread and common diseases of the increasingly aging society worldwide. There is growing evidence that regularly performed exercise is a powerful therapy against the progression of cardiovascular diseases, cancer, neurodegenerative diseases, psychiatric disorders, and chronic pulmonary diseases (Pedersen and Saltin 2015). For prevention of these noncommunicable diseases, the World Health Organization (WHO) has developed "global recommendations on physical activity for health" (WHO 2010). These wellacknowledged benefits of exercise go far beyond the molecular adaptations of working skeletal muscle and include enhanced substrate delivery and oxidation capacity and increased mechanical strength and power (Egan and Zierath 2013). For decades, researchers have focused on elucidating the mechanisms by which the energy-demanding mechanical work of skeletal muscle can impact the entire body to promote profound health benefits. In 1961, Goldstein conducted cross-transfusion experiments between resting dogs and dogs in which muscle contraction was induced by electrical stimulation (Goldstein 1961). Based on his data, he postulated the exis-

Editors: Juleen R. Zierath, Michael J. Joyner, and John A. Hawley

Additional Perspectives on The Biology of Exercise available at www.perspectivesinmedicine.org

Copyright (C) 2017 Cold Spring Harbor Laboratory Press; all rights reserved; doi: 10.1101/cshperspect.a029793

Cite this article as Cold Spring Harb Perspect Med 2017; 7:a029793 
tence of humoral components induced by muscular work that enhance glucose utilization in the resting dogs. In 1983, a pyrogenic substance with an estimated molecular weight of $14 \mathrm{kDa}$ was reported in human plasma after $1 \mathrm{~h}$ of bicycling, although a specific factor could not be identified (Cannon and Kluger 1983). The detection of increased expression of the cytokine interleukin 6 (IL-6) in human muscle biopsies obtained following exercise (Ostrowski et al. 1998b) and the concomitant release of this muscle-derived IL-6 into the circulation (Steensberg et al. 2000) was then the starting point for a new research field. The concept of myokines was introduced to describe putative cytokines that are produced and released by muscle fibers and exert endocrine effects (Pedersen et al. 2003). Since then, the list of myokines is constantly growing and the classification has become more loosely interpreted to include any secreted protein that is produced in skeletal muscle whether it acts in an autocrine, paracrine, or endocrine manner (Pedersen and Febbraio 2012). The focus of this review is on exerciseregulated myokines and does not touch on the numerous myokines that have been described in differentiating skeletal muscle cell cultures (Henningsen et al. 2010; Chan et al. 2011) in the context of muscle injury (Zeng et al. 2010) or mitochondrial dysfunction (Ost et al. 2016). We will give an overview on the current knowledge of human myokines and discuss the evidence for an autocrine, paracrine, or endocrine role in the health-promoting effects of exercise and the potential therapeutic options.

\section{THE HUMAN SKELETAL MUSCLE SECRETOME}

The idea of endogenous factors that are released from human skeletal muscle as hormone-like mediators of the preventive and therapeutic effects of exercise has initiated proteomics and transcriptomics profiling approaches to elucidate the composition of the skeletal muscle secretome and to identify novel myokines. Global and targeted proteomic profiling was applied to the secretome of cultured primary human myotubes to provide a comprehensive description of secreted proteins (Hittel et al. 2009; Bouzakri et al. 2011; Le Bihan et al. 2012; Hartwig et al. 2014). About two-thirds of the more than 1000 proteins identified in cultured primary human myotube secretome were predicted or have been annotated as putative secreted proteins, underlining the potency of skeletal muscle to act as an endocrine organ (Weigert et al. 2014). Functional term analysis of these proteins suggests an important paracrine function in skeletal muscle development and regeneration, extracellular matrix (ECM) organization, and angiogenesis. At least a part of the proteins not assigned as potentially secreted forms are carried in microvesicles such as exosomes (Le Bihan et al. 2012).

To investigate exercise-regulated myokines, analyses of transcripts in exercised human skeletal muscle were combined with profiling of secreted proteins in cultured muscle cells (Norheim et al. 2011) or quantification of myokine plasma levels (Catoire et al. 2014b). In vitro exercise by applying electric pulse stimulation to cultured human skeletal muscle cells was used for antibody-based microarray profiling of the supernatant (Raschke et al. 2013a; Scheler et al. 2013). None of these studies came close to providing a complete picture of the exercise-induced release of myokines into muscle interstitial fluid or the circulation. One explanation is that plasma and interstitial fluid represent two of the most challenging secretomes for proteomics profiling, because a few highly abundant protein species are responsible for $\sim 99 \%$ of the protein content and these disguise other proteins such as cytokines of comparably very low concentration in the picomolar or femtomolar range (Anderson and Anderson 2002). To circumvent this problem, different approaches have been developed and are currently optimized to enrich the low abundant proteins (Frobel et al. 2015; Gianazza et al. 2016).

The majority of the hitherto assigned exercise-regulated myokines with putative endocrine functions were identified by targeted approaches analyzing transcript and protein level in human skeletal muscle biopsies and plasma following one acute bout of exercise or after training. An overview of exercise-regulated human myokines with exercise-mediated changes 
in mRNA and protein abundance in skeletal muscle or plasma is given in Table 1. The proteins secreted by skeletal muscle can often be released from a wide variety of cells, including immune cells, endothelial cells, fibroblasts, osteocytes, hepatocytes, and adipocytes. Therefore, elevated systemic concentrations of these proteins after exercise or in the supernatant of primary human muscle cells only suggest, and do not prove, the existence of an exercise-regulated myokine. The list is dominated by cytokines, growth factors, and regulators or components of the ECM.

Moreover, transgenic expression of transcriptional key regulator peroxisome proliferator-activated receptor coactivator (PGC) $1 \alpha$ in skeletal muscle led to the discovery of irisin and meteorin-like as exercise-regulated myokines that stimulate energy expenditure and brown fat-like development in mice (Bostrom et al. 2012; Rao et al. 2014). Meteorin-like as well as myonectin (CTRP15) (Seldin et al. 2012) and musclin (OSTN) (Subbotina et al. 2015) have only been described in rodent studies, and human data on the regulation of intramuscular and systemic levels of these proteins following exercise have not been reported to date.

\section{EXERCISE-REGULATED HUMAN MYOKINES}

Experimental evidence for an exercise-induced production in and secretion from human muscle is provided for several cytokines, including IL-6, IL-8, IL-10, IL-15, CC-chemokine ligand (CCL)2, IL-1 receptor antagonist, calprotectin S100A9, and vascular endothelial growth factor (VEGF) with increased interstitial fluid concentrations in skeletal muscle following exercise or a net release from skeletal muscle measured as arterial-venous differences (see Table 1 for details). At least increased mRNA and protein abundance in human skeletal muscle following acute exercise or training is described for angiopoietin-like 4 (ANGPTL4), brain-derived neurotrophic factor (BDNF), connective tissue growth factor (CTGF), cysteine-rich angiogenic protein 61 (CYR61), fractalkine, and nicotinamide phosphoribosyl transferase (NAMPT). An increase of cytokines in the muscular inter- stitial fluid can be seen after 30 min of onelegged knee extensor exercise or rowing and may occur independent of a transcriptional response (Rosendal et al. 2005; Rue et al. 2014). However, elevated transcript or protein levels are not always paralleled by increased systemic concentrations, as reported for CTGF, CYR61, IL-8, IL-15, LIF, and VEGF (Ostrowski et al. 1998a; Nieman et al. 2003; Broholm et al. 2011; Catoire et al. 2014b; Landers-Ramos et al. 2014). In general, systemic cytokine responses are more pronounced after exercise with a higher degree of muscle damage such as downhill running, eccentric exercise, and resistance training (Paulsen et al. 2012). Moreover, a robust elevation of the transcript abundance of several cytokines and chemokines in skeletal muscle is regularly described after exercise bouts with long duration or high intensity (Nieman et al. 2001; Suzuki et al. 2006; Neubauer et al. 2014) but less pronounced or absent after more moderate intense physical activity (Catoire et al. 2014b; Hansen et al. 2015b). Notably, the increased expression and release of IL-6 and to some extent of other cytokines occurs independent of muscle damage. The increase in IL-6 is not linked to the release in tumor necrosis factor $\alpha$ (TNF- $\alpha$ ) (Steensberg et al. 2002; Keller et al. 2006) or other markers of tissue injury (Croisier et al. 1999; Starkie et al. 2001) but is regulated by carbohydrate availability and proposed to serve as a sensor of the metabolic status of the muscle (Keller et al. 2001; Steensberg et al. 2001; MacDonald et al. 2003). Low muscle glycogen content preexercise results in higher IL-6 and IL-8 transcript levels postexercise (Chan et al. 2004). Furthermore, carbohydrate ingestion before exercise attenuates the increase in these transcripts (Nieman et al. 2003). In addition, a recent study in rodents shows that the release of the bone-derived hormone osteocalcin induces part of the exercise-induced increase in IL-6 and enhanced substrate oxidation capacity (Mera et al. 2016), which shows the ability of bone to sense mechanical forces and to act as regulator of myokines in response to exercise.

Not all of the exercised-regulated cytokines are localized to myofibers; satellite cells, fibro- 


\section{Hoffmann and C. Weigert}
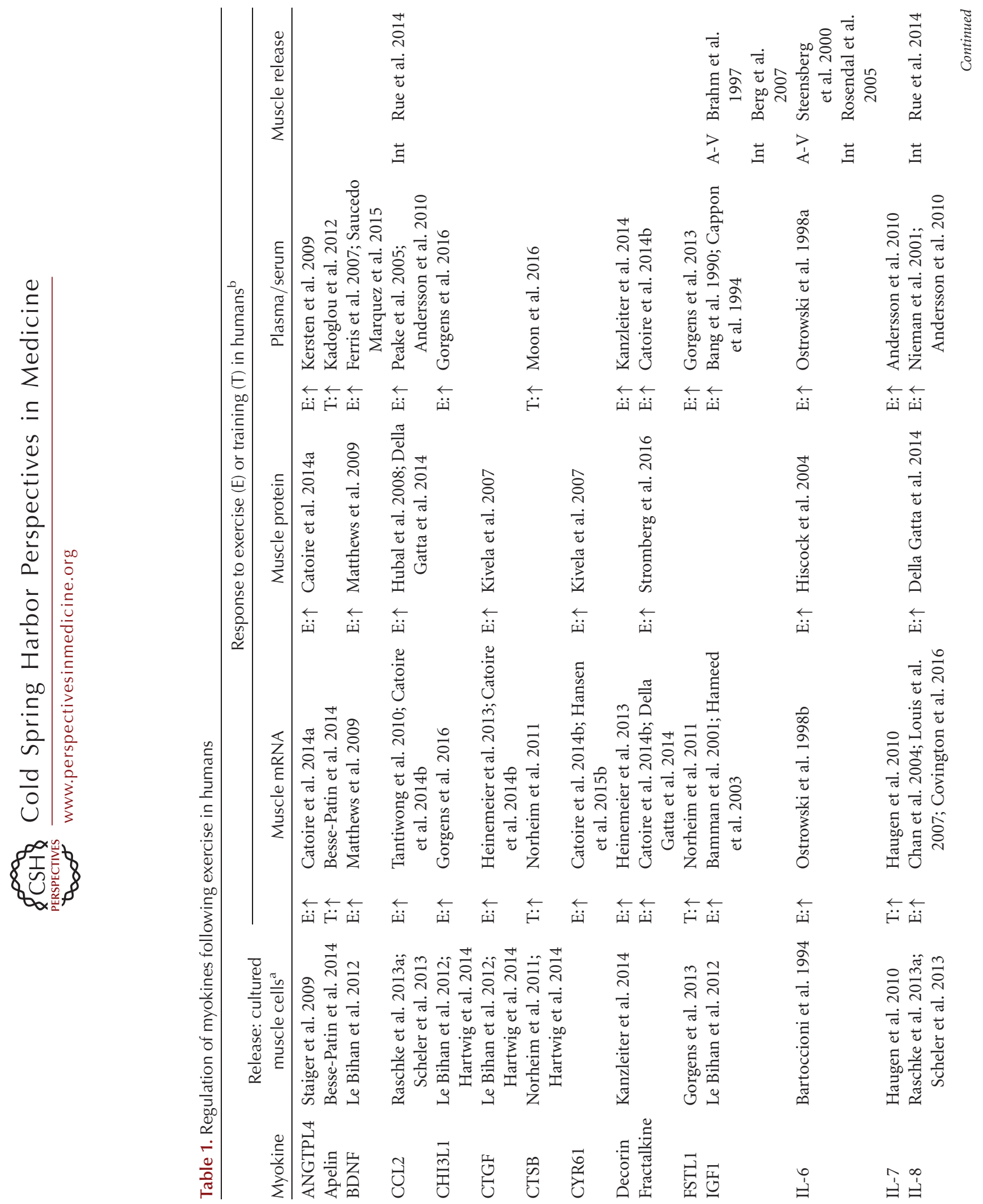
Myokines in Exercise Adaptations
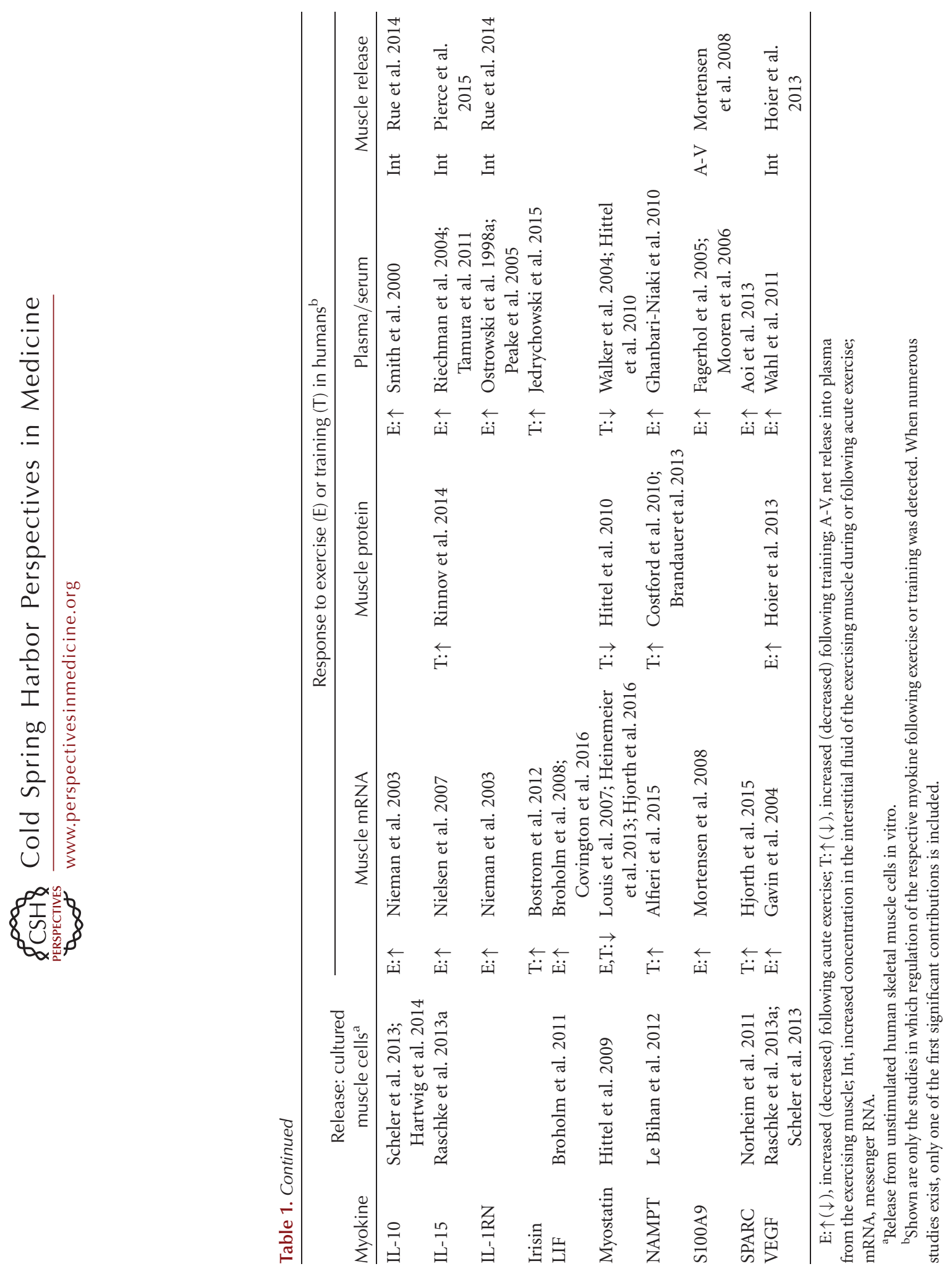
C. Hoffmann and C. Weigert

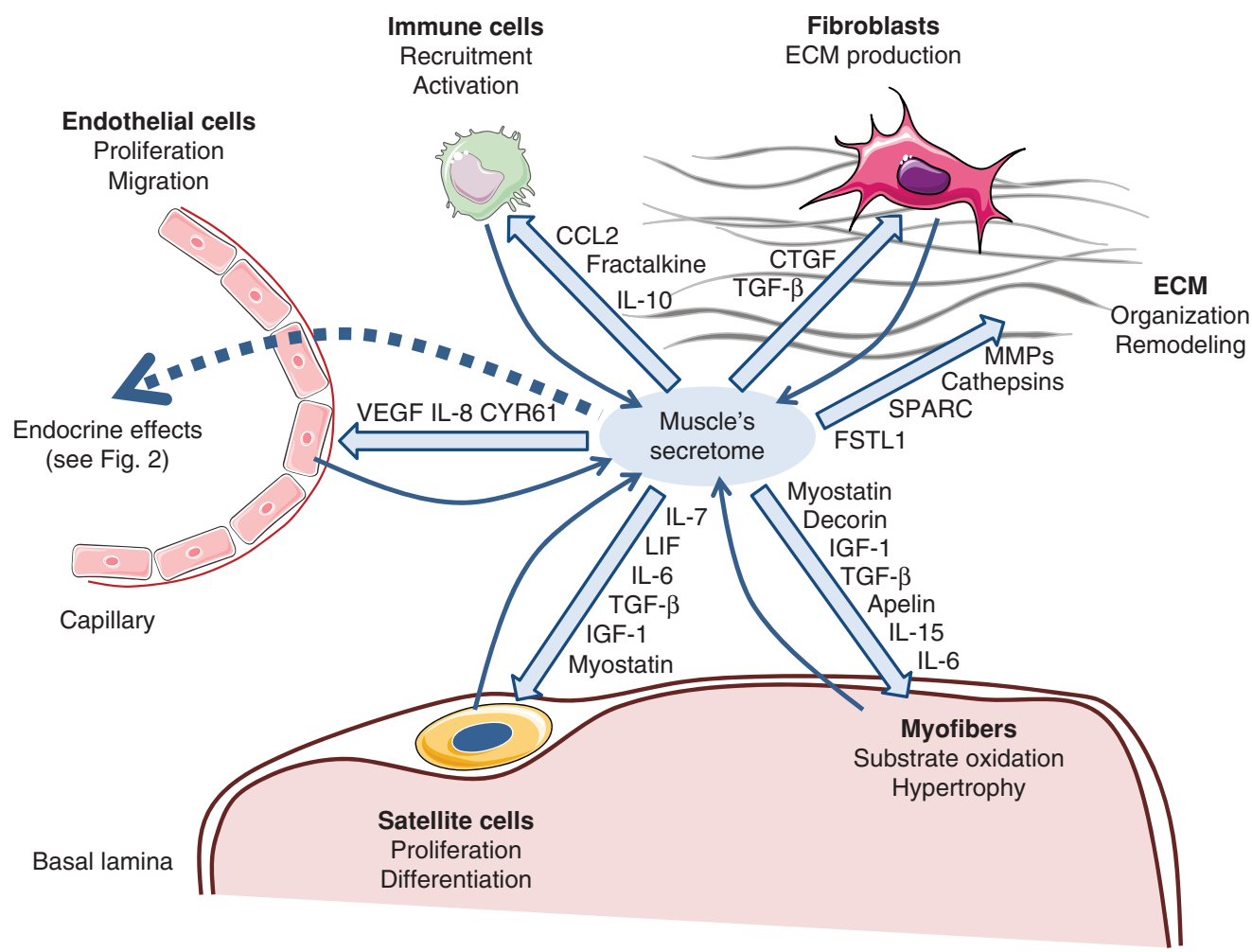

Figure 1. Autocrine and paracrine effects of exercise-regulated human myokines. Myofibers, satellite cells, fibroblasts, immune cells, and endothelial cells contribute to the secretome of muscle, which also includes proteins of the extracellular matrix (ECM). Shown are the autocrine and paracrine functions of exercise- or training-regulated human myokines on the different cell types and structures within muscle tissue. The effect of myokines can be both stimulatory or inhibitory. CCL2, CC-chemokine ligand 2; CTGF, connective tissue growth factor; TGF- $\beta$, transforming growth factor $\beta$; IL, interleukin; MMPs, matrix metalloproteinases; VEGF, vascular endothelial growth factor; SPARC, secreted protein rich in cysteine; FSTL1, follistatin-like 1; LIF, leukemia inhibitory factor; IGF-1, insulin-like growth factor 1. (Figure created using illustrations provided by Servier Medical Art.)

blasts, endothelial cells, and macrophages residing in muscle tissue can contribute to muscular abundance and release of proteins (Fig. 1). IL-6 is primarily localized in myofibers (Hiscock et al. 2004), but also detected in satellite cells (McKay et al. 2009) and fibroblasts (Malm et al. 2004). CCL2 is detected in macrophages and satellite cells (Hubal et al. 2008; Della Gatta et al. 2014), LIF in endothelial cells (Malm et al. 2004), IL-8 in macrophages and blood vessels (Della Gatta et al. 2014), and fractalkine in the endothelium (Stromberg et al. 2016). VEGF is localized to myofibers, endothelial cells, and pericytes (Hoier et al. 2013). It is common practice to use the term "myokine" irre- spective of the validation of myofibers as origin of the released protein.

\section{IL-6-A MULTITALENTED MYOKINE}

IL- 6 is the best-studied myokine and can serve as a prime example for the potential of exerciseregulated myokines with well-described auto-, para-, and endocrine effects. Acting in an autocrine/paracrine manner in skeletal muscle, IL6-dependent STAT3 signaling was detected in human satellite cells after muscle-lengthening contraction (Toth et al. 2011). IL-6 is important for hypertrophic muscle growth and myogenesis in mice (Serrano et al. 2008). Myotube for- 
mation is reduced in IL-6-deficient primary mouse skeletal muscle cells (Hoene et al. 2013). Endocrine effects assigned to the exercise-induced release of IL- 6 fit into the concept of health-promoting myokines. IL-6 increases insulin-stimulated glucose disposal and glucose oxidation (Carey et al. 2006) and stimulates lipolysis and fat oxidation (van Hall et al. 2003; Petersen et al. 2005). On the molecular level, these effects are mediated via IL-6-dependent activation of AMP-activated protein kinase (AMPK) (Ruderman et al. 2006), regulation of insulin receptor substrate-1 (Weigert et al. 2006), and PI3-kinase (Al Khalili et al. 2006). Rodent studies provide evidence that IL-6 enhances expansion of pancreatic $\alpha$ cells (Ellingsgaard et al. 2008) and improves insulin secretion and hyperglycemia via stimulation of glucagen-like peptide 1 (GLP1) secretion from the $L$ cells in the intestine and pancreatic $\alpha$ cells (Ellingsgaard et al. 2011). IL-6 promotes the alternative activation of macrophages, which is involved in the protection from obesity-induced tissue inflammation and insulin resistance (Mauer et al. 2014). Recently, exercise was reported to reduce tumor size and growth in mice via IL-6-dependent natural killer cell mobilization (Pedersen et al. 2016). To conclude, the exercise-induced release of IL-6 may partly account for important beneficial effects of exercise, including improved glycemic control, loss of fat mass, suppression of tumor growth, and maintenance of muscle mass.

\section{MYOSTATIN - RENEWED INTEREST IN AN "OLD" MYOKINE}

The first identified myokine, even though not termed a myokine at the time of its discovery, was myostatin (McPherron et al. 1997). Myostatin is the myokine with probably the most pronounced effects on muscle mass and body fat composition. Myostatin is expressed and secreted by skeletal muscle and acts as a negative regulator of skeletal muscle growth (McPherron et al. 1997). Mutations in the human MSTN gene leading to reduced production of mature myostatin protein increase muscle mass with a concomitant loss of adipose tissue (Schuelke et al. 2004). Myostatin received new attention as a potential target to treat the metabolic syndrome because myostatin transcript levels are higher in skeletal muscle of type 2 diabetes patients (Palsgaard et al. 2009) and myostatin plasma levels are elevated in obese women (Hittel et al. 2009). Regular exercise reduces myostatin transcript levels in skeletal muscle of obese subjects and people with impaired glycemic control, but decreased mRNA abundance was also found after one acute bout of exercise in healthy people (Table 1). Myostatin deficiency or inhibition of myostatin signaling improves insulin resistance in old and obese mice (Zhao et al. 2005; Wilkes et al. 2009; Camporez et al. 2016). The underlying mechanisms are not completely clear, because direct effects of myostatin on insulin signaling in skeletal muscle cells or adipocytes could not be detected (Hjorth et al. 2016).

\section{ROLE OF MYOKINES IN EXERCISE ADAPTATIONS}

Myokines are involved in many of exercise-induced adaptations. In the following sections, the potential contribution of myokines to an enhanced exercise capacity and the benefits for whole-body metabolism and prevention of chronic diseases is presented. To date, functional data are mainly based on mouse and in vitro studies.

\section{Regulation of Metabolic Pathways}

The beneficial effect of exercise on glycemic control and lipid homeostasis was one of the initial driving forces in searching for musclederived factors as "exercise-mimetics" for the treatment of metabolic disorders such as type 2 diabetes. Besides the exercise-induced acute increase in IL- 6 and the reduction in myostatin, other exercise-regulated myokines play a potential role in the regulation of metabolism following exercise.

The exercise-induced increase in ANGPTL4 plasma levels has been involved in the regulation of plasma triglycerides by decreasing lipoprotein lipase (LPL) activity (Dijk et al. 2016) and promoting adipose tissue lipolysis (Gray et al. 
2012). Beyond that, ANGPTL4 was recently described in mice as mediator of hyperplasia of pancreatic $\alpha$ cells (Ben Zvi et al. 2015). Apelin is a ligand of the G-protein-coupled receptor APJ. In rodents, apelin increases glucose uptake and mitochondrial oxidative capacity in skeletal muscle (Dray et al. 2008; Attane et al. 2012). However, the contribution of skeletal musclederived apelin to plasma levels is questionable (Yamamoto et al. 2011). IL-15 signaling might be involved in regulation of muscle fiber composition, contractility, and body fat composition. Mouse models lacking the IL-15 $\alpha$ receptor in skeletal muscle suggest an intramuscular role for IL-15 in defining the shift to fast glycolytic fibers, with the loss of IL- $15 \alpha$ receptor signaling increasing oxidative exercise capacity and resistance to fatigue (Pistilli et al. 2011). Conversely, transgenic mice with skeletal muscle overexpression of IL-15 also have a high endurance capacity (Quinn et al. 2013). Moreover, mice with oversecretion of IL-15 from skeletal muscle showed increased lean body mass and decreased body fat content (Quinn et al. 2009). NAMPT is the rate-limiting enzyme in the NAD salvage pathway responsible for converting NAM to NAD. Increased NAMPT protein levels in skeletal muscle following training are related to enhanced mitochondrial density in athletes (Costford et al. 2010; Brandauer et al. 2013). However, the increase in intracellular NAMPT is probably not associated with a regulation of extracellular eNAMPT, also known as Visfatin (Revollo et al. 2007). Irisin is cleaved from the fibronectin type III domain-containing protein 5 (FNDC5) and induces browning of white fat and thermogenesis in mice (Bostrom et al. 2012). After its discovery in mice, the existence of irisin in humans was questioned (Raschke et al. 2013b), and questions were raised regarding the validity of the commercial ELISA kits used for quantification of human irisin (Albrecht et al. 2015). Recently, irisin was identified in human plasma by mass spectrometry (Jedrychowski et al. 2015).

To conclude, several myokines have been implicated in the reduction of subcutaneous and visceral fat and enhanced substrate oxidation capacity, two main effectors of whole-body insulin sensitivity. Further exercise adaptations presented in the next sections, such as the increase in muscle mass, the increase in muscle capillarization, and the reduction in systemic inflammation also contribute to the improvement in substrate oxidation and glycemic control.

\section{The Anti-Inflammatory Effect of Exercise}

From the first report regarding the production and release of inflammatory cytokines by contracting skeletal muscle, the notion that exercise induces muscle damage and inflammation has been discussed. An important paracrine function of these cytokines in the muscle is to attract immune cells to control inflammatory processes and to support muscle regeneration following exercise. CCL2, also known as monocyte chemotactic protein (MCP)1, and fractalkine, also known as chemokine (C-X3-C motif) ligand $(\mathrm{CX} 3 \mathrm{CL}) 1$, regulate migration and infiltration of monocytes and macrophages. These factors are involved in the recruitment of macrophages and other immune cells in muscle and are important for tissue repair following injuries (Pillon et al. 2012). IL-10 and the IL-1 receptor antagonist are part of the anti-inflammatory response counteracting the function of other cytokines on multiple levels (Maynard and Weaver 2008). Moreover, muscle-specific overexpression of IL-10 prevents diet-induced inflammation and insulin resistance (Hong et al. 2009).

The anti-inflammatory potential of exercise is reflected by the decrease in systemic concentrations of several inflammatory cytokines following training interventions, which is particularly observed in chronic diseases that are associated with a low grade systemic inflammatory state such as obesity and insulin resistance, cardiovascular diseases, atherosclerosis, and neurodegenerative disorders (Gleeson et al. 2011; Lancaster and Febbraio 2014). The reduction in systemic levels of proinflammatory cytokines is mediated by multiple mechanism including a reduction in visceral fat mass, increased production and release of anti-inflammatory cytokines IL-10 and IL-1 receptor antagonist presumably via IL-6 (Steensberg 
et al. 2003), down-regulation of toll-like receptor signaling (Stewart et al. 2005; Oliveira and Gleeson 2010), a shift in the monocyte populations in blood to a less proinflammatory phenotype (Timmerman et al. 2008), and activation of immune suppressive $\mathrm{T}$ cells (Yeh et al. 2006). Other myokines such as IL-7 or CHI3L1 may contribute as well to the anti-inflammatory effects (Schluns et al. 2000; Gorgens et al. 2014), but the specific contribution of single myokines to the anti-inflammatory effect of exercise is difficult to unravel because of their multiple sources and their tightly interacting network.

The exercise-induced release of inflammatory cytokines can be seen as a hormetic mechanism, that is, a beneficial response to a stress-inducing condition involved in the improvement of exercise capacity, substrate oxidation, and the anti-inflammatory effect of regular performed exercise. In this regard, interfering with the exercise-induced inflammation by nonsteroidal anti-inflammatory drugs (NSAIDs) can reduce the acute increase in skeletal muscle protein synthesis (Trappe et al. 2002) and the activation of satellite cells (Mikkelsen et al. 2009); but studies investigating the effect of chronic consumption of NSAIDs during training on the gain in muscle mass or strength showed no interference or even a beneficial effect in older adults (Trappe et al. 2011; Jankowski et al. 2013). In rodent studies, NSAID treatment has in general negative effects on muscle regeneration, muscle hypertrophy, but also on mitochondrial adaptations (Machida and Takemasa 2010; Urso 2013). These data support a role of the exercise-induced inflammatory response beyond immune modulatory functions. The importance of cellular stress signals in the health-promoting effects of exercise is further emphasized by the adverse effects of antioxidant treatments during training, which reduce the improvement of muscle mitochondrial function and insulin sensitivity, implicating the generation of reactive oxygen species as mediators of exercise adaptations (Ristow et al. 2009; Strobel et al. 2011). Whether an altered myokine response is involved in the undesired effects of NSAIDs and antioxidant treatment during exercise remains to be proven.

\section{Regulation of Myogenesis and Muscle Hypertrophy}

Increases in muscle mass and muscle hypertrophy are important adaptations to regular training, in particular to resistance exercise. The insulin-like growth factor 1 (IGF-1) locally increases in exercising muscle and is proposed to mediate some of the effects of training on muscle mass by promoting hypertrophy (Velloso 2008). Other exercise-regulated myokines increase the proliferation of primary human skeletal muscle cells, including decorin ( $\mathrm{Li}$ et al. 2007), LIF (Broholm et al. 2011), and CHI3L1 (Gorgens et al. 2016) or, as already mentioned for IL-6 and is also shown for IL-7, are involved in myogenesis (Haugen et al. 2010). The reduced abundance of the muscle growth inhibitor, myostatin, in trained skeletal muscle and altered regulation of myostatin activity can also contribute to muscle hypertrophy. Decorin enhances skeletal muscle regeneration in mice by inhibiting myostatin and increasing promyogenic factors (Kanzleiter et al. 2014).

\section{Adaptation of the Vascular System}

Exercise training induces pronounced systemic cardiovascular adaptations, such as increased cardiac output and enhanced blood volume. Muscle-derived factors have been implicated in mediating the local effects of exercise training to increase capillarization in skeletal muscle and improve oxygen supply and utilization (Hoier and Hellsten 2014). The most important angiogenic factor induced in skeletal muscle on acute exercise is VEGF (Olfert et al. 2016). On a systemic level, plasma VEGF levels are often unaltered in response to exercise, pointing toward primarily local effects (Landers-Ramos et al. 2014). CYR61 or CCN1 and CTGF or CCN2 belong to a family of ECM-associated proteins. Both are localized to capillaries, and CYR61 is also present in myofibers (Kivela et al. 2007). Like VEGF, local increases in CYR61 and CTGF following exercise are well-described, whereas no elevation on the systemic level has been described. Both regulate angiogenesis, in part by promoting VEGF expression, endothe- 
lial cell function, and the ECM (Perbal 2004). IL-8 activates endothelial cell proliferation and capillary tube organization (Li et al. 2003); therefore, IL- 8 has been proposed to play a role in skeletal muscle angiogenesis. However, a recent study came to an opposite conclusion, showing that elevated IL-8 secretion from human myotubes impairs capillary outgrowth (Amir et al. 2015). Besides the regulation of lipid metabolism, ANGPTL4 also regulates angiogenesis and vascular permeability (Babapoor-Farrokhran et al. 2015). Muscle-specific deficiency or overexpression of follistatin-like 1 (FSTL1) in mice reveals a beneficial effect on vascular repair processes (Miyabe et al. 2014).

\section{Muscle-Bone Interactions}

Muscle contraction influences bone mass during development and growth, as well as bone density, risk of fractures, and fracture healing in adults. Mechanical stimuli are considered as driving forces in this relationship (Turner 2006), but there is also evidence that exerciseinduced muscle-derived factors regulate bone formation and bone health. Myostatin inhibits bone repair, and consequently myostatin antagonists improve fracture healing (Hamrick et al. 2010). In contrast, IGF-1 (Doorn et al. 2013) and secreted protein rich in cysteine (SPARC) have osteogenic properties and are positively associated with bone mineralization (Breen et al. 2011; Pataquiva-Mateus et al. 2012). Bone mineral content is also increased by muscle-specific oversecretion of IL-15 (Quinn et al. 2009).

\section{Improvement of Cognitive Function}

Cognitive function can be improved and preserved by regular physical activity (Duzel et al. 2016). An important factor in that regard is BDNF, which regulates synaptic plasticity, cell survival, and differentiation in the brain (Chao et al. 2006). Elevated systemic levels of BDNF following acute exercise are frequently reported, but increases in BDNF mRNA and protein abundance in skeletal muscle are apparently not associated with a release of the protein (Matthews et al. 2009). However, in mouse models, two muscle-derived factors have been linked to increased BDNF abundance in the hippocampus. Exercise induces the expression of FNDC5 not only in muscle, but also in hippocampus, which leads to increased BDNF levels and neuroprotection in this region (Wrann et al. 2013). This action can also be achieved by elevation of circulating irisin levels. The exercise-induced release of cathepsin B (CTSB) from skeletal muscle in mice was implicated in the improved memory function mediated by enhanced BDNF expression in the hippocampus (Moon et al. 2016). This is supported by human data showing that exercise training increases CTSB mRNA levels in muscle, as well as systemic protein level, which is correlated with cognitive functions (Moon et al. 2016).

\section{Cancer Protection}

Regular physical activity is recommended to reduce the risk for developing various tumors. Cytokines derived from exercise-conditioned mouse serum or electrical stimulated muscle cells can inhibit cancer cell proliferation (Hojman et al. 2011). The exercise-dependent mobilization of natural killer cells plays a central role in reducing tumor growth, and the myokines IL- 6 and IL-15 regulate maturation and redistribution of natural killer cells (Idorn and Hojman 2016). Moreover, studies in mice support a role of exercise-induced SPARC in suppressing colon tumorigenesis by enhancing apoptosis in colon cells (Aoi et al. 2013).

\section{PHYSIOLOGICAL RELEVANCE OF ENDOCRINE EFFECTS OF MYOKINES}

The importance of exercise-induced myokines in the regulation of immunomodulatory processes, in angiogenesis, and in remodeling the ECM in muscle is well established. Exercise-induced myokines play a central role in orchestrating the interaction of myofibers, immune cells, fibroblasts, and endothelial cells (Fig. 1). In addition, the release of neurotrophic factors such as BNDF and neurotrophic factor- 4 have been proposed to be involved in promoting survival and function of motoneurons (Nishimune et al. 
2014). Thus, myokines are of crucial importance for the adaptation of skeletal muscle to an increased physical workload. Moreover, as described above, there are several exercise-regulated muscle-derived factors with proposed endocrine effects (summarized in Fig. 2). The biological effects attributed to myokines comprise more or less all beneficial consequences of regular physical activity. However, the extent to which endocrine effects of muscle-derived factors contribute to the health-promoting effects of exercise in humans is still unclear. First of all, for many myokines, whether the increase in transcript and protein abundance in muscle is translated into increased systemic levels is uncertain. The studies of Steensberg provide evidence that skeletal muscle accounts for a major part of the systemic elevation in IL-6 following exercise (Steensberg et al. 2000; Toft et al. 2011), but data for many other myokines is lacking. Fibroblast growth factor 21 (FGF-21) has been classified as a myokine, because its expression in skeletal muscle is increased several-fold in mouse models with mitochondrial disorders (Kim et al. 2013a; Keipert et al. 2014). Moreover, serum levels of FGF-21 are elevated after acute exercise (Kim et al. 2013b). However, analyzing the flux of FGF-21 over the exercising muscle and over the hepatosplanchnic bed in humans reveals liver, rather than skeletal muscle, is the main contributor to exercise-induced systemic increases in FGF-21 (Hansen et al. 2015a). Other myokines showed a pronounced up-regulation following exercise in other organs-for example, exercise also induces a marked ANGPTL4 expression in liver (Kersten et al. 2009) — and the contribution of skeletal muscle to systemic ANGPTL4 levels following exercise requires further clarification.

To elucidate the relevance of individual myokines for a role in exercise adaptations, it turned out to be a challenge to generate appropriate animal models. Muscle-specific overexpression of myokines in mice needs to be finetuned to yield a physiologically relevant local and systemic concentration and should ideally mimic the transient changes. Because of the expression and release of most myokines from several tissues and their pleiotropic functions, whole-body knockout mice are less helpful in this context. There is the need for convincing transgenic mouse models specifically targeting the exercise-regulated release of myokines from skeletal muscle. This proved to be more challenging than expected. Skeletal muscle-specific IL-6 knockout mice appear to have higher systemic IL-6 levels following exercise (Gudiksen et al. 2016), which again shows the tight regulation and importance of feedback control mechanisms in the cytokine network.

\section{FURTHER PERSPECTIVES}

\section{Role of the Extracellular Matrix in Exercise Adaptations}

Structural proteins of the ECM are released by their cellular sources within skeletal muscle and are highly abundant in the supernatant of cultured skeletal muscle cells (Weigert et al. 2014). Moreover, transcriptional and proteomics profiling of the skeletal muscle following acute exercise and training revealed a large number of regulated ECM proteins, including several collagens, proteoglycans, and modulators of the ECM such as cathepsins and matrix metalloproteinases (Rullman et al. 2007; Norheim et al. 2011; Heinemeier et al. 2013; Catoire et al. 2014b; Hjorth et al. 2015; Hyldahl et al. 2015).

Although most of the regulated ECM components may not have direct signaling properties, the importance of the dynamic nature of the ECM of skeletal muscle for mechanotransduction, force transmission to tendons, protection against force-induced injury, exercise-induced angiogenesis, and ECM-residing progenitor cells is well-acknowledged (Kjaer 2004; Gustafsson 2011). Notably, skeletal muscle insulin resistance is accompanied by increased collagen content (Berria et al. 2006) and decreased desmin and actinin-2 content (Hwang et al. 2010). Alterations in the ECM, such as the content of hyaluronan, have been proposed to act as a physical barrier and influence glucose and insulin delivery (Kang et al. 2013; Williams et al. 2015), whereas alterations in desmin or actinin can influence mechanosignal transduction and translocation of glucose transporter-4 (Coletta 

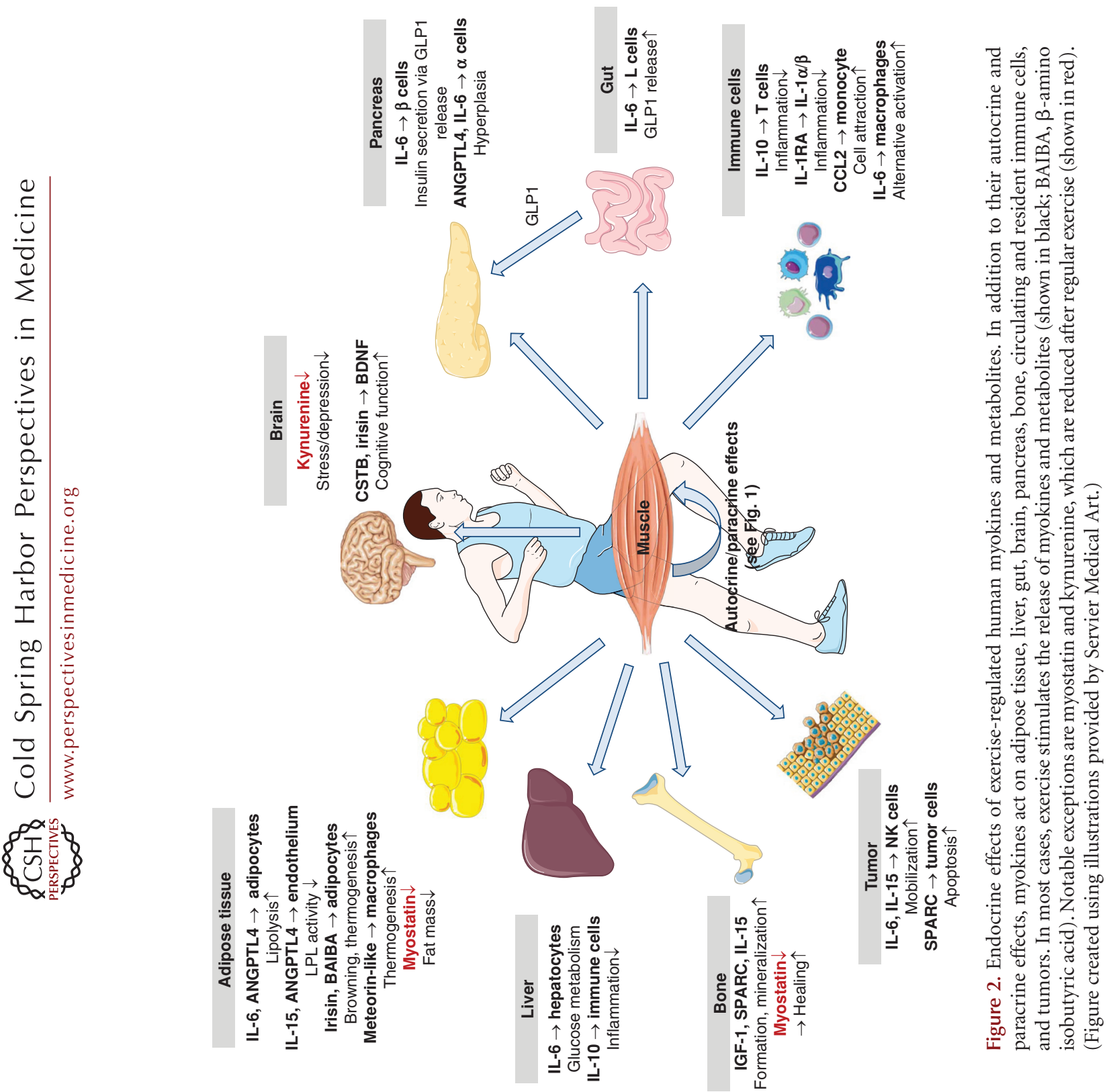
and Mandarino 2011). Mutations in collagen VI lead to defective muscle microfibril formation and mitochondrial dysfunction (Bushby et al. 2014; Zamurs et al. 2015). Furthermore, $\mathrm{ECM}$-integrin receptor interaction is involved in diet-induced insulin resistance in mouse models (Kang et al. 2016). Another regulatory level of signal transduction in skeletal muscle is the binding, release, and presentation of growth factors such as VEGF and transforming growth factor $\beta$ (TGF- $\beta$ ) by the ECM (Hynes 2009), which can be directly influenced by the exercise-dependent remodeling of the ECM. Thus, several modes of interaction exist between the ECM and myofibers within skeletal muscle that can be involved in exercise-induced adaptations including improved metabolism and exercise capacity.

\section{TGF- $\beta$ as Potential Regulator of Metabolic Adaptations}

The TGF- $\beta$ protein family is of great importance for muscle development and regeneration (Kollias and McDermott 2008). TGF- $\beta$ is an inhibitor of myogenic differentiation (Massague et al. 1986) and plays an important role in inflammatory process after muscle injury and fibrosis (Mann et al. 2011). After acute exercise or training, mRNA abundance of TGF- $\beta 1$ and TGF- $\beta$ receptor 2 is increased (Heinemeier et al. 2013). Moreover, TGF- $\beta$ signaling can be enhanced by release of active TGF- $\beta$ protein from a large latent complex in the ECM by exercise-activated metalloproteinases or mechanical force-mediated activation via integrin signaling (Hynes 2009), but the contribution of these mechanisms to the enhanced TGF- $\beta$ signaling following exercise needs to be clarified. Numerous TGF- $\beta$ target transcripts, such as the TGF- $\beta$ inducible protein and other ECM proteins, are increased after exercise and training (Heinemeier et al. 2013; Neubauer et al. 2014). Thus, TGF- $\beta$ contributes to the adaptation of the ECM to exercise. Recently, TGF- $\beta$ has also been implicated in the exercise-dependent regulation of PGC1 $\alpha$ and substrate oxidation capacity of skeletal muscle (Tiano et al. 2015; Bohm et al. 2016). TGF- $\beta 1$ down-regulates sev- eral mitochondrial key regulators and enzymes in primary human skeletal muscle cells and activated TGF- $\beta$ signaling may account for the failure to enhance insulin sensitivity in some subjects after training (Bohm et al. 2016). This effect of TGF- $\beta$ is not restricted to skeletal muscle, because whole-body blockade of TGF- $\beta$ signaling in obese mice improves mitochondrial respiration in adipocytes, hepatic steatosis, glucose tolerance, and energy homeostasis (Yadav et al. 2011). Thus, TGF- $\beta$ appears to be relevant not only for the ECM composition and inflammatory processes but also for improvements in glycemic control after exercise training.

\section{FUTURE DIRECTIONS}

\section{Myometabokines}

The secretome of skeletal muscle not only comprises proteins and peptides but also metabolites and lipids. These factors can contribute to the health-promoting effects of exercise not only caused by altered substrate fluxes between organs but also based on the potential of some metabolites and lipids to activate surface or intracellular receptors (Schoonjans et al. 1996; Itoh et al. 2003; Hashimoto et al. 2007; Cao et al. 2008). These factors can act as musclederived paracrine or endocrine factors and are termed "myometabokines." Metabolomics and lipidomics analyses of arterial and venous plasma samples of the exercising leg enable the identification of a wide range of metabolites and lipids released from skeletal muscle ( $\mathrm{Xu}$ et al. 2016). In rodent studies, two interesting candidates with endocrine function have been identified. $\beta$-Amino isobutyric acid is released from cultured muscle cells and increased in plasma of exercising mice and trained humans. $\beta$-Amino isobutyric acid contributes to the browning of white fat and hepatic fat oxidation (Roberts et al. 2014). Exercise training increases kynurenine aminotransferase in skeletal muscle, inducing a shift in circulating kynurenine to kynurenic acid in both mice and humans, which is proposed to be involved in the protection from stress-induced depressive disorders (Agudelo et al. 2014; Schlittler et al. 2016). 


\section{MyomiRs}

Other recently discovered components of the muscle's secretome include regulatory, noncoding RNA molecules (micro-RNA [miRNA], long noncoding RNA [lncRNA]) (CoenenStass et al. 2016). Exercise and training regulates the plasma miRNA profile in humans (Baggish et al. 2011; Nielsen et al. 2014), which differs from the miRNA signature in exercised or trained muscle (Nielsen et al. 2010; Russell et al. 2013). Muscle-enriched miRNA (referred to as myomiRs) are involved in the regulation of myogenic processes and circulating miRNAs responding to exercise are associated with angiogenesis, inflammation, and mitochondrial dynamics, and a role in the adaptation to exercise is discussed (Russell and Lamon 2015). MyomiRs are also found in exosomes, interesting new players of the muscle's secretome, because they can carry a whole array of exercise-regulated factors, thereby transporting the health-promoting information of exercise to other tissues (Safdar et al. 2016).

\section{Therapeutic Potential of Exercise-Regulated Myokines}

Although future research will provide more insight into the relevance of endocrine effects of single myokines or other muscle-derived factors, the increasing knowledge about the biological function of exercise-regulated musclederived factors is a valuable source for novel therapeutic options to treat chronic diseases. However, the transient regulation of most myokines by exercise- a sharp increase in systemic levels, followed by a decline within hours-is a very important aspect when considering the therapeutic potential of myokines, because chronically elevated systemic concentrations of most cytokines and ECM-regulating growth factors are associated with conditions of prolonged and uncontrolled inflammation and are found in many diseases, including autoimmune diseases, cancer, and obesity-related metabolic disorders, or muscular dystrophies (Akira et al. 1993; Gabay 2006; Hoene and Weigert 2008; Burks and Cohn 2011).
In the case of myostatin with its clear function in regulating muscle mass and body fat content, a soluble form of the activin receptor type IIB, which blocks myostatin (Lee et al. 2016), was tested in a double-blind, placebocontrolled study in 48 healthy women and was shown to increase total lean body mass and muscle volume (Attie et al. 2013). Based on the multiple potential beneficial effects of IL-6, current research is also focusing on the development of novel gp130 ligands. IL-6 and other cytokines share signaling via a gp130/ $\alpha$ receptor complex (Heinrich et al. 2003). Among them is CNTF, which has weight-lowering effects in mice (Watt et al. 2006) and humans (Ettinger et al. 2003). The design of new gp130 ligands, by combining the beneficial signaling properties and abolishing the negative effects, which in the case of IL-6 is triggering proinflammatory reactions, has been proposed to be a promising future goal (Cron et al. 2016).

\section{CONCLUDING REMARKS}

Based on the current state of knowledge, the major physiological function of the secretory capability of skeletal muscle is to protect and improve the functionality of the working muscle by regulating the intramuscular cross talk of myofibers, immune cells, fibroblasts, the vasculature, and the bone. Furthermore, there is convincing evidence that factors secreted by skeletal muscle act as endocrine signaling mediators and are involved in the beneficial effects of exercise on almost all cell types and organs. The entire secretome of exercising skeletal muscle has not yet been described. Thus, novel components, including metabolites, lipids, and RNA molecules, will add additional regulatory levels to the interorgan cross talk. Because of the complexity of not only the muscle's secretome, an "exercise mimetic" might not be possible, and efforts to motivate people to increase their daily physical activity should even be intensified. But research has started to develop modified myokines that combine the beneficial effects and omit the undesired side effects, aiming to support the treatment of chronic diseases. 


\section{ACKNOWLEDGMENTS}

C.W. acknowledges collaborators, in particular, Peter Plomgaard and Bente Klarlund Pedersen, The Centre of Inflammation and Metabolism and the Centre for Physical Activity Research, the Department of Infectious Diseases and Community Regional Medical Center (CMRC), Rigshospitalet, Copenhagen, Denmark, and Stefan Lehr, Institute for Clinical Biochemistry and Pathobiochemistry, German Diabetes Center, Leibniz Center for Diabetes Research at the Heinrich Heine University Düsseldorf, Düsseldorf, Germany, who contributed much to my understanding of myokines. The work of C.H. and C.W. is supported by a Grant (01GI0925) from the German Federal Ministry of Education and Research (BMBF) to the German Center for Diabetes Research (DZD e.V.) and by a Grant from the Leibniz Gemeinschaft (SAW-FBN2013-3).

\section{REFERENCES}

Agudelo LZ, Femenia T, Orhan F, Porsmyr-Palmertz M, Goiny M, Martinez-Redondo V, Correia JC, Izadi M, Bhat M, Schuppe-Koistinen I, et al. 2014. Skeletal muscle PGC- $1 \alpha 1$ modulates kynurenine metabolism and mediates resilience to stress-induced depression. Cell 159: $33-$ 45.

Akira S, Taga T, Kishimoto T. 1993. Interleukin-6 in biology and medicine. Adv Immunol 54: 1-78.

Albrecht E, Norheim F, Thiede B, Holen T, Ohashi T, Schering L, Lee S, Brenmoehl J, Thomas S, Drevon CA, et al. 2015. Irisin - A myth rather than an exercise-inducible myokine. Sci Rep 5: 8889.

Alfieri A, Martone D, Randers MB, Labruna G, Mancini A, Nielsen JJ, Bangsbo J, Krustrup P, Buono P. 2015. Effects of long-term football training on the expression profile of genes involved in muscle oxidative metabolism. Mol Cell Probes 29: 43-47.

Al Khalili L, Bouzakri K, Glund S, Lonnqvist F, Koistinen HA, Krook A. 2006. Signaling specificity of interleukin-6 action on glucose and lipid metabolism in skeletal muscle. Mol Endocrinol 20: 3364-3375.

Amir LY, Ciaraldi TP, Mudaliar SR, Phillips SA, Henry RR. 2015. Excessive secretion of IL-8 by skeletal muscle in type 2 diabetes impairs tube growth: Potential role of PI3K and the Tie2 receptor. Am J Physiol Endocrinol Metab 309: E22-E34.

Anderson NL, Anderson NG. 2002. The human plasma proteome: History, character, and diagnostic prospects. Mol Cell Proteomics 1: 845-867.

Andersson H, Bohn SK, Raastad T, Paulsen G, Blomhoff R, Kadi F. 2010. Differences in the inflammatory plasma cytokine response following two elite female soccer games separated by a $72-\mathrm{h}$ recovery. Scand J Med Sci Sports 20: 740-747.

Aoi W, Naito Y, Takagi T, Tanimura Y, Takanami Y, Kawai Y, Sakuma K, Hang LP, Mizushima K, Hirai Y, et al. 2013. A novel myokine, secreted protein acidic and rich in cysteine (SPARC), suppresses colon tumorigenesis via regular exercise. Gut 62: 882-889.

Attane C, Foussal C, Le Gonidec S, Benani A, Daviaud D, Wanecq E, Guzman-Ruiz R, Dray C, Bezaire V, Rancoule C, et al. 2012. Apelin treatment increases complete fatty acid oxidation, mitochondrial oxidative capacity, and biogenesis in muscle of insulin-resistant mice. Diabetes 61: 310-320.

Attie KM, Borgstein NG, Yang Y, Condon CH, Wilson DM, Pearsall AE, Kumar R, Willins DA, Seehra JS, Sherman ML. 2013. A single ascending-dose study of muscle regulator ACE-031 in healthy volunteers. Muscle Nerve 47: 416-423.

Babapoor-Farrokhran S, Jee K, Puchner B, Hassan SJ, Xin X, Rodrigues M, Kashiwabuchi F, Ma T, Hu K, Deshpande M, et al. 2015. Angiopoietin-like 4 is a potent angiogenic factor and a novel therapeutic target for patients with proliferative diabetic retinopathy. Proc Natl Acad Sci 112: E3030-E3039.

Baggish AL, Hale A, Weiner RB, Lewis GD, Systrom D, Wang F, Wang TJ, Chan SY. 2011. Dynamic regulation of circulating microRNA during acute exhaustive exercise and sustained aerobic exercise training. J Physiol 589: $3983-$ 3994.

Bamman MM, Shipp JR, Jiang J, Gower BA, Hunter GR, Goodman A, McLafferty CLJr, Urban RJ. 2001. Mechanical load increases muscle IGF-I and androgen receptor mRNA concentrations in humans. Am J Physiol Endocrinol Metab 280: E383-E390.

Bang P, Brandt J, Degerblad M, Enberg G, Kaijser L, Thoren M, Hall K. 1990. Exercise-induced changes in insulin-like growth factors and their low molecular weight binding protein in healthy subjects and patients with growth hormone deficiency. Eur J Clin Invest 20: 285-292.

Bartoccioni E, Michaelis D, Hohlfeld R. 1994. Constitutive and cytokine-induced production of interleukin- 6 by human myoblasts. Immunol Lett 42: 135-138.

Ben Zvi D, Barrandon O, Hadley S, Blum B, Peterson QP, Melton DA. 2015. Angptl4 links $\alpha$-cell proliferation following glucagon receptor inhibition with adipose tissue triglyceride metabolism. Proc Natl Acad Sci 112: 15498-15503.

Berg U, Gustafsson T, Sundberg CJ, Kaijser L, CarlssonSkwirut C, Bang P. 2007. Interstitial IGF-I in exercising skeletal muscle in women. Eur J Endocrinol 157: 427-435.

Berria R, Wang L, Richardson DK, Finlayson J, Belfort R, Pratipanawatr T, De Filippis EA, Kashyap S, Mandarino LJ. 2006. Increased collagen content in insulin-resistant skeletal muscle. Am J Physiol Endocrinol Metab 290: E560-E565.

Besse-Patin A, Montastier E, Vinel C, Castan-Laurell I, Louche K, Dray C, Daviaud D, Mir L, Marques MA, Thalamas C, et al. 2014. Effect of endurance training on skeletal muscle myokine expression in obese men: Identification of apelin as a novel myokine. Int J Obes (Lond) 38: 707-713.

Bohm A, Hoffmann C, Irmler M, Schneeweiss P, Schnauder G, Sailer C, Schmid V, Hudemann J, Machann J, Schick F, 
et al. 2016. TGF $\beta$ contributes to impaired exercise response by suppression of mitochondrial key regulators in skeletal muscle. Diabetes 65: 2849-2861.

Bostrom P, Wu J, Jedrychowski MP, Korde A, Ye L, Lo JC, Rasbach KA, Bostrom EA, Choi JH, Long JZ, et al. 2012. A PGC1- $\alpha$-dependent myokine that drives brown-fatlike development of white fat and thermogenesis. Nature 481: 463-468.

Bouzakri K, Plomgaard P, Berney T, Donath MY, Pedersen BK, Halban PA. 2011. Bimodal effect on pancreatic $\beta$ cells of secretory products from normal or insulin-resistant human skeletal muscle. Diabetes 60: 1111-1121.

Brahm H, Piehl-Aulin K, Saltin B, Ljunghall S. 1997. Net fluxes over working thigh of hormones, growth factors and biomarkers of bone metabolism during short lasting dynamic exercise. Calcif Tissue Int 60: 175-180.

Brandauer J, Vienberg SG, Andersen MA, Ringholm S, Risis S, Larsen PS, Kristensen JM, Frosig C, Leick L, Fentz J, et al. 2013. AMP-activated protein kinase regulates nicotinamide phosphoribosyl transferase expression in skeletal muscle. J Physiol 591: 5207-5220.

Breen ME, Laing EM, Hall DB, Hausman DB, Taylor RG, Isales CM, Ding KH, Pollock NK, Hamrick MW, Baile CA, et al. 2011. 25-Hydroxyvitamin D, insulin-like growth factor-I, and bone mineral accrual during growth. J Clin Endocrinol Metab 96: E89-E98.

Broholm C, Mortensen OH, Nielsen S, Akerstrom T, Zankari A, Dahl B, Pedersen BK. 2008. Exercise induces expression of leukaemia inhibitory factor in human skeletal muscle. J Physiol 586: 2195-2201.

Broholm C, Laye MJ, Brandt C, Vadalasetty R, Pilegaard H, Pedersen BK, Scheele C. 2011. LIF is a contraction-induced myokine stimulating human myocyte proliferation. J Appl Physiol (1985) 111: 251-259.

Burks TN, Cohn RD. 2011. Role of TGF- $\beta$ signaling in inherited and acquired myopathies. Skelet Muscle 1: 19.

Bushby KM, Collins J, Hicks D. 2014. Collagen type VI myopathies. Adv Exp Med Biol 802: 185-199.

Camporez JP, Petersen MC, Abudukadier A, Moreira GV, Jurczak MJ, Friedman G, Haqq CM, Petersen KF, Shulman GI. 2016. Anti-myostatin antibody increases muscle mass and strength and improves insulin sensitivity in old mice. Proc Natl Acad Sci 113: 2212-2217.

Cannon JG, Kluger MJ. 1983. Endogenous pyrogen activity in human plasma after exercise. Science 220: 617-619.

Cao H, Gerhold K, Mayers JR, Wiest MM, Watkins SM, Hotamisligil GS. 2008. Identification of a lipokine, a lipid hormone linking adipose tissue to systemic metabolism. Cell 134: 933-944.

Cappon J, Brasel JA, Mohan S, Cooper DM. 1994. Effect of brief exercise on circulating insulin-like growth factor I. $J$ Appl Physiol (1985) 76: 2490-2496.

Carey AL, Steinberg GR, Macaulay SL, Thomas WG, Holmes AG, Ramm G, Prelovsek O, Hohnen-Behrens C, Watt MJ, James DE, et al. 2006. Interleukin-6 increases insulin-stimulated glucose disposal in humans and glucose uptake and fatty acid oxidation in vitro via AMPactivated protein kinase. Diabetes 55: 2688-2697.

Catoire M, Alex S, Paraskevopulos N, Mattijssen F, Evers-van Gogh I, Schaart G, Jeppesen J, Kneppers A, Mensink M, Voshol PJ, et al. 2014a. Fatty acid-inducible ANGPTL4 governs lipid metabolic response to exercise. Proc Natl Acad Sci 111: E1043-E1052.

Catoire M, Mensink M, Kalkhoven E, Schrauwen P, Kersten S. 2014b. Identification of human exercise-induced myokines using secretome analysis. Physiol Genomics 46: 256-267.

Chan MH, Carey AL, Watt MJ, Febbraio MA. 2004. Cytokine gene expression in human skeletal muscle during concentric contraction: Evidence that IL-8, like IL-6, is influenced by glycogen availability. Am J Physiol Regul Integr Comp Physiol 287: R322-R327.

Chan CY, Masui O, Krakovska O, Belozerov VE, Voisin S, Ghanny S, Chen J, Moyez D, Zhu P, Evans KR, et al. 2011. Identification of differentially regulated secretome components during skeletal myogenesis. Mol Cell Proteomics 10: M110.

Chao MV, Rajagopal R, Lee FS. 2006. Neurotrophin signalling in health and disease. Clin Sci (Lond) 110: 167-173.

Coenen-Stass AM, Betts CA, Lee YF, Mager I, Turunen MP, El Andaloussi S, Morgan JE, Wood MJ, Roberts TC. 2016. Selective release of muscle-specific, extracellular microRNAs during myogenic differentiation. Hum Mol Genet doi: $10.1093 / \mathrm{hmg} / \mathrm{ddw} 237$.

Coletta DK, Mandarino LJ. 2011. Mitochondrial dysfunction and insulin resistance from the outside in: Extracellular matrix, the cytoskeleton, and mitochondria. Am J Physiol Endocrinol Metab 301: E749-E755.

Costford SR, Bajpeyi S, Pasarica M, Albarado DC, Thomas SC, Xie H, Church TS, Jubrias SA, Conley KE, Smith SR. 2010. Skeletal muscle NAMPT is induced by exercise in humans. Am J Physiol Endocrinol Metab 298: E117-E126.

Covington JD, Tam CS, Bajpeyi S, Galgani JE, Noland RC, Smith SR, Redman LM, Ravussin E. 2016. Myokine expression in muscle and myotubes in response to exercise stimulation. Med Sci Sports Exerc 48: 384-390.

Croisier JL, Camus G, Venneman I, Deby-Dupont G, Juchmes-Ferir A, Lamy M, Crielaard JM, Deby C, Duchateau J. 1999. Effects of training on exercise-induced muscle damage and interleukin 6 production. Muscle Nerve 22: 208-212.

Cron L, Allen T, Febbraio MA. 2016. The role of gp130 receptor cytokines in the regulation of metabolic homeostasis. J Exp Biol 219: 259-265.

Della Gatta PA, Cameron-Smith D, Peake JM. 2014. Acute resistance exercise increases the expression of chemotactic factors within skeletal muscle. Eur J Appl Physiol 114: 2157-2167.

Dijk W, Beigneux AP, Larsson M, Bensadoun A, Young SG, Kersten S. 2016. Angiopoietin-like 4 (ANGPTL4) promotes intracellular degradation of lipoprotein lipase in adipocytes. J Lipid Res 57: 1670-1683.

Doorn J, Roberts SJ, Hilderink J, Groen N, van Apeldoorn A, van Blitterswijk C, Schrooten J, de Boer J. 2013. Insulinlike growth factor-I enhances proliferation and differentiation of human mesenchymal stromal cells in vitro. Tissue Eng Part A 19: 1817-1828.

Dray C, Knauf C, Daviaud D, Waget A, Boucher J, Buleon M, Cani PD, Attane C, Guigne C, Carpene C, et al. 2008. Apelin stimulates glucose utilization in normal and obese insulin-resistant mice. Cell Metab 8: 437-445. 
Duzel E, van Praag H, Sendtner M. 2016. Can physical exercise in old age improve memory and hippocampal function? Brain 139: 662-673.

Egan B, Zierath JR. 2013. Exercise metabolism and the molecular regulation of skeletal muscle adaptation. Cell Metab 17: 162-184.

Ellingsgaard H, Ehses JA, Hammar EB, Van Lommel L, Quintens R, Martens G, Kerr-Conte J, Pattou F, Berney T, Pipeleers D, et al. 2008. Interleukin-6 regulates pancreatic $\alpha$-cell mass expansion. Proc Natl Acad Sci 105: $13163-13168$.

Ellingsgaard H, Hauselmann I, Schuler B, Habib AM, Baggio LL, Meier DT, Eppler E, Bouzakri K, Wueest S, Muller YD, et al. 2011. Interleukin-6 enhances insulin secretion by increasing glucagon-like peptide-1 secretion from L cells and $\alpha$ cells. Nat Med 17: 1481-1489.

Ettinger MP, Littlejohn TW, Schwartz SL, Weiss SR, McIlwain $\mathrm{HH}$, Heymsfield SB, Bray GA, Roberts WG, Heyman ER, Stambler N, et al. 2003. Recombinant variant of ciliary neurotrophic factor for weight loss in obese adults: A randomized, dose-ranging study. JAMA 289: 1826-1832.

Fagerhol MK, Nielsen HG, Vetlesen A, Sandvik K, Lyberg T 2005. Increase in plasma calprotectin during long-distance running. Scand J Clin Lab Invest 65: 211-220.

Ferris LT, Williams JS, Shen CL. 2007. The effect of acute exercise on serum brain-derived neurotrophic factor levels and cognitive function. Med Sci Sports Exerc 39: 728-734.

Frobel J, Hartwig S, Jourdain S, Fischer JC, Zilkens C, Kundgen A, Suckau D, Germing U, Czibere A, Lehr S. 2015. Deep serum discoveries: SDF- $1 \alpha$ and HSA fragments in myelodysplastic syndromes. Am J Hematol 90: E185-E187.

Gabay C. 2006. Interleukin-6 and chronic inflammation. Arthritis Res Ther 8: S3.

Gavin TP, Robinson CB, Yeager RC, England JA, Nifong LW, Hickner RC. 2004. Angiogenic growth factor response to acute systemic exercise in human skeletal muscle. J Appl Physiol (1985) 96: 19-24.

Ghanbari-Niaki A, Saghebjoo M, Soltani R, Kirwan JP. 2010. Plasma visfatin is increased after high-intensity exercise. Ann Nutr Metab 57: 3-8.

Gianazza E, Miller I, Palazzolo L, Parravicini C, Eberini I. 2016. With or without you-Proteomics with or without major plasma/serum proteins. J Proteomics 140: 62-80.

Gleeson M, Bishop NC, Stensel DJ, Lindley MR, Mastana SS, Nimmo MA. 2011. The anti-inflammatory effects of exercise: Mechanisms and implications for the prevention and treatment of disease. Nat Rev Immunol 11: 607-615.

Goldstein MS. 1961. Humoral nature of the hypoglycemic factor of muscular work. Diabetes 10: 232-234.

Gorgens SW, Raschke S, Holven KB, Jensen J, Eckardt K, Eckel J. 2013. Regulation of follistatin-like protein $1 \mathrm{ex}-$ pression and secretion in primary human skeletal muscle cells. Arch Physiol Biochem 119: 75-80.

Gorgens SW, Eckardt K, Elsen M, Tennagels N, Eckel J. 2014. Chitinase-3-like protein 1 protects skeletal muscle from $\mathrm{TNF} \alpha$-induced inflammation and insulin resistance. $\mathrm{Bi}$ ochem J 459: 479-488.

Gorgens SW, Hjorth M, Eckardt K, Wichert S, Norheim F, Holen T, Lee S, Langleite T, Birkeland KI, Stadheim HK, et al. 2016. The exercise-regulated myokine chitinase-3- like protein 1 stimulates human myocyte proliferation. Acta Physiol (Oxf) 216: 330-345.

Gray NE, Lam LN, Yang K, Zhou AY, Koliwad S, Wang JC. 2012. Angiopoietin-like 4 (Angptl4) protein is a physiological mediator of intracellular lipolysis in murine adipocytes. J Biol Chem 287: 8444-8456.

Gudiksen A, Schwartz CL, Bertholdt L, Joensen E, Knudsen JG, Pilegaard H. 2016. Lack of skeletal muscle IL-6 affects pyruvate dehydrogenase activity at rest and during prolonged exercise. PLOS ONE 11: e0156460.

Gustafsson T. 2011. Vascular remodelling in human skeletal muscle. Biochem Soc Trans 39: 1628-1632.

Hameed M, Orrell RW, Cobbold M, Goldspink G, Harridge SD. 2003. Expression of IGF-I splice variants in young and old human skeletal muscle after high resistance exercise. J Physiol 547: 247-254.

Hamrick MW, Arounleut P, Kellum E, Cain M, Immel D, Liang LF. 2010. Recombinant myostatin (GDF-8) propeptide enhances the repair and regeneration of both muscle and bone in a model of deep penetrant musculoskeletal injury. J Trauma 69: 579-583.

Hansen JS, Clemmesen JO, Secher NH, Hoene M, Drescher A, Weigert C, Pedersen BK, Plomgaard P. 2015a. Glucagon-to-insulin ratio is pivotal for splanchnic regulation of FGF-21 in humans. Mol Metab 4: 551-560.

Hansen JS, Zhao X, Irmler M, Liu X, Hoene M, Scheler M, Li Y, Beckers J, Hrabe dA, Haring HU, et al. 2015b. Type 2 diabetes alters metabolic and transcriptional signatures of glucose and amino acid metabolism during exercise and recovery. Diabetologia 58: 1845-1854.

Hartwig S, Raschke S, Knebel B, Scheler M, Irmler M, Passlack W, Muller S, Hanisch FG, Franz T, Li X, et al. 2014. Secretome profiling of primary human skeletal muscle cells. Biochim Biophys Acta 1844: 1011-1017.

Hashimoto T, Hussien R, Oommen S, Gohil K, Brooks GA. 2007. Lactate sensitive transcription factor network in L6 cells: Activation of MCT1 and mitochondrial biogenesis. FASEB J 21: 2602-2612.

Haugen F, Norheim F, Lian H, Wensaas AJ, Dueland S, Berg O, Funderud A, Skalhegg BS, Raastad T, Drevon CA. 2010. IL-7 is expressed and secreted by human skeletal muscle cells. Am J Physiol Cell Physiol 298: C807-C816.

Heinemeier KM, Bjerrum SS, Schjerling P, Kjaer M. 2013. Expression of extracellular matrix components and related growth factors in human tendon and muscle after acute exercise. Scand J Med Sci Sports 23: e150-e161.

Heinrich PC, Behrmann I, Haan S, Hermanns HM, MullerNewen G, Schaper F. 2003. Principles of interleukin (IL)6-type cytokine signalling and its regulation. Biochem J 374: $1-20$.

Henningsen J, Rigbolt KT, Blagoev B, Pedersen BK, Kratchmarova I. 2010. Dynamics of the skeletal muscle secretome during myoblast differentiation. Mol Cell Proteomics 9: 2482-2496.

Hiscock N, Chan MH, Bisucci T, Darby IA, Febbraio MA. 2004. Skeletal myocytes are a source of interleukin-6 mRNA expression and protein release during contraction: Evidence of fiber type specificity. FASEB J 18: 992-994.

Hittel DS, Berggren JR, Shearer J, Boyle K, Houmard JA. 2009. Increased secretion and expression of myostatin in 
skeletal muscle from extremely obese women. Diabetes 58: $30-38$.

Hittel DS, Axelson M, Sarna N, Shearer J, Huffman KM, Kraus WE. 2010. Myostatin decreases with aerobic exercise and associates with insulin resistance. Med Sci Sports Exerc 42: 2023-2029.

Hjorth M, Norheim F, Meen AJ, Pourteymour S, Lee S, Holen T, Jensen J, Birkeland KI, Martinov VN, Langleite TM, et al. 2015. The effect of acute and long-term physical activity on extracellular matrix and serglycin in human skeletal muscle. Physiol Rep 3: e12473.

Hjorth M, Pourteymour S, Gorgens SW, Langleite TM, Lee S, Holen T, Gulseth HL, Birkeland KI, Jensen J, Drevon CA, et al. 2016. Myostatin in relation to physical activity and dysglycaemia and its effect on energy metabolism in human skeletal muscle cells. Acta Physiol (Oxf) 217: 45-60.

Hoene M, Weigert C. 2008. The role of interleukin-6 in insulin resistance, body fat distribution and energy balance. Obes $\operatorname{Rev}$ 9: 20-29.

Hoene M, Runge H, Haring HU, Schleicher ED, Weigert C. 2013. Interleukin-6 promotes myogenic differentiation of mouse skeletal muscle cells: Role of the STAT3 pathway. Am J Physiol Cell Physiol 304: C128-C136.

Hoier B, Hellsten Y. 2014. Exercise-induced capillary growth in human skeletal muscle and the dynamics of VEGF Microcirculation 21: 301-314.

Hoier B, Prats C, Qvortrup K, Pilegaard H, Bangsbo J, Hellsten Y. 2013. Subcellular localization and mechanism of secretion of vascular endothelial growth factor in human skeletal muscle. FASEB J 27: 3496-3504.

Hojman P, Dethlefsen C, Brandt C, Hansen J, Pedersen L, Pedersen BK. 2011. Exercise-induced muscle-derived cytokines inhibit mammary cancer cell growth. Am J Physiol Endocrinol Metab 301: E504-E510.

Hong EG, Ko HJ, Cho YR, Kim HJ, Ma Z, Yu TY, Friedline RH, Kurt-Jones E, Finberg R, Fischer MA, et al. 2009. Interleukin-10 prevents diet-induced insulin resistance by attenuating macrophage and cytokine response in skeletal muscle. Diabetes 58: 2525-2535.

Hubal MJ, Chen TC, Thompson PD, Clarkson PM. 2008. Inflammatory gene changes associated with the repeatedbout effect. Am J Physiol Regul Integr Comp Physiol 294: R1628-R1637.

Hwang H, Bowen BP, Lefort N, Flynn CR, De Filippis EA Roberts C, Smoke CC, Meyer C, Hojlund K, Yi Z, et al. 2010. Proteomics analysis of human skeletal muscle reveals novel abnormalities in obesity and type 2 diabetes. Diabetes 59: 33-42.

Hyldahl RD, Nelson B, Xin L, Welling T, Groscost L, Hubal MJ, Chipkin S, Clarkson PM, Parcell AC. 2015. Extracellular matrix remodeling and its contribution to protective adaptation following lengthening contractions in human muscle. FASEB J 29: 2894-2904.

Hynes RO. 2009. The extracellular matrix: Not just pretty fibrils. Science 326: 1216-1219.

Idorn M, Hojman P. 2016. Exercise-dependent regulation of NK cells in cancer protection. Trends Mol Med 22: 565577.

Itoh Y, Kawamata Y, Harada M, Kobayashi M, Fujii R, Fukusumi S, Ogi K, Hosoya M, Tanaka Y, Uejima H, et al.
2003. Free fatty acids regulate insulin secretion from pancreatic $\beta$ cells through GPR40. Nature 422: 173-176.

Jankowski CM, Gozansky WS, MacLean PS, Shulman B, Wolfe P, Schwartz RS, Kohrt WM. 2013. N-acetyl-4-aminophenol and musculoskeletal adaptations to resistance exercise training. Eur J Appl Physiol 113: 1127-1136.

Jedrychowski MP, Wrann CD, Paulo JA, Gerber KK, Szpyt J, Robinson MM, Nair KS, Gygi SP, Spiegelman BM. 2015. Detection and quantitation of circulating human irisin by tandem mass spectrometry. Cell Metab 22: 734-740.

Kadoglou NP, Vrabas IS, Kapelouzou A, Lampropoulos S, Sailer N, Kostakis A, Liapis CD, Angelopoulou N. 2012. The impact of aerobic exercise training on novel adipokines, apelin and ghrelin, in patients with type 2 diabetes. Med Sci Monit 18: CR290-CR295.

Kang L, Lantier L, Kennedy A, Bonner JS, Mayes WH, Bracy DP, Bookbinder LH, Hasty AH, Thompson CB, Wasserman DH. 2013. Hyaluronan accumulates with high-fat feeding and contributes to insulin resistance. Diabetes 62: 1888-1896.

Kang L, Mokshagundam S, Reuter B, Lark DS, Sneddon CC, Hennayake C, Williams AS, Bracy DP, James FD, Pozzi A, et al. 2016. Integrin-linked kinase in muscle is necessary for the development of insulin resistance in diet-induced obese mice. Diabetes 65: 1590-1600.

Kanzleiter T, Rath M, Gorgens SW, Jensen J, Tangen DS, Kolnes AJ, Kolnes KJ, Lee S, Eckel J, Schurmann A, et al. 2014. The myokine decorin is regulated by contraction and involved in muscle hypertrophy. Biochem Biophys Res Commun 450: 1089-1094.

Keipert S, Ost M, Johann K, Imber F, Jastroch M, van Schothorst EM, Keijer J, Klaus S. 2014. Skeletal muscle mitochondrial uncoupling drives endocrine cross-talk through the induction of FGF21 as a myokine. Am J Physiol Endocrinol Metab 306: E469-E482.

Keller C, Steensberg A, Pilegaard H, Osada T, Saltin B, Pedersen BK, Neufer PD. 2001. Transcriptional activation of the IL- 6 gene in human contracting skeletal muscle: Influence of muscle glycogen content. FASEB J 15: 27482750.

Keller C, Hellsten Y, Steensberg A, Pedersen BK. 2006. Differential regulation of IL- 6 and TNF- $\alpha$ via calcineurin in human skeletal muscle cells. Cytokine 36: 141-147.

Kersten S, Lichtenstein L, Steenbergen E, Mudde K, Hendriks HF, Hesselink MK, Schrauwen P, Muller M. 2009. Caloric restriction and exercise increase plasma ANGPTL4 levels in humans via elevated free fatty acids. Arterioscler Thromb Vasc Biol 29: 969-974.

Kim KH, Jeong YT, Oh H, Kim SH, Cho JM, Kim YN, Kim SS, Kim dH, Hur KY, Kim HK, et al. 2013a. Autophagy deficiency leads to protection from obesity and insulin resistance by inducing Fgf21 as a mitokine. Nat Med 19: 83-92.

Kim KH, Kim SH, Min YK, Yang HM, Lee JB, Lee MS. 2013b. Acute exercise induces FGF21 expression in mice and in healthy humans. PLoS ONE 8: e63517.

Kivela R, Kyrolainen H, Selanne H, Komi PV, Kainulainen H, Vihko V. 2007. A single bout of exercise with high mechanical loading induces the expression of Cyr61/ CCN1 and CTGF/CCN2 in human skeletal muscle. $J$ Appl Physiol 103: 1395-1401. 
Kjaer M. 2004. Role of extracellular matrix in adaptation of tendon and skeletal muscle to mechanical loading. Physiol Rev 84: 649-698.

Kollias HD, McDermott JC. 2008. Transforming growth factor- $\beta$ and myostatin signaling in skeletal muscle. J Appl Physiol (1985) 104: 579-587.

Lancaster GI, Febbraio MA. 2014. The immunomodulating role of exercise in metabolic disease. Trends Immunol 35: 262-269.

Landers-Ramos RQ, Jenkins NT, Spangenburg EE, Hagberg JM, Prior SJ. 2014. Circulating angiogenic and inflammatory cytokine responses to acute aerobic exercise in trained and sedentary young men. Eur J Appl Physiol 114: $1377-1384$

Le Bihan MC, Bigot A, Jensen SS, Dennis JL, RogowskaWrzesinska A, Laine J, Gache V, Furling D, Jensen ON, Voit T, et al. 2012. In-depth analysis of the secretome identifies three major independent secretory pathways in differentiating human myoblasts. J Proteomics 77: 344-356.

Lee YS, Huynh TV, Lee SJ. 2016. Paracrine and endocrine modes of myostatin action. J Appl Physiol (1985) 120: 592-598.

Li A, Dubey S, Varney ML, Dave BJ, Singh RK. 2003. IL-8 directly enhanced endothelial cell survival, proliferation, and matrix metalloproteinases production and regulated angiogenesis. J Immunol 170: 3369-3376.

Li Y, Li J, Zhu J, Sun B, Branca M, Tang Y, Foster W, Xiao X, Huard J. 2007. Decorin gene transfer promotes muscle cell differentiation and muscle regeneration. Mol Ther 15: 1616-1622.

Louis E, Raue U, Yang Y, Jemiolo B, Trappe S. 2007. Time course of proteolytic, cytokine, and myostatin gene expression after acute exercise in human skeletal muscle. $J$ Appl Physiol (1985) 103: 1744-1751.

MacDonald C, Wojtaszewski JF, Pedersen BK, Kiens B, Richter EA. 2003. Interleukin-6 release from human skeletal muscle during exercise: Relation to AMPK activity. J Appl Physiol 95: 2273-2277.

Machida M, Takemasa T. 2010. Ibuprofen administration during endurance training cancels running-distance-dependent adaptations of skeletal muscle in mice. J Physiol Pharmacol 61: 559-563.

Malm C, Sjodin TL, Sjoberg B, Lenkei R, Renstrom P, Lundberg IE, Ekblom B. 2004. Leukocytes, cytokines, growth factors and hormones in human skeletal muscle and blood after uphill or downhill running. J Physiol 556: 983-1000.

Mann CJ, Perdiguero E, Kharraz Y, Aguilar S, Pessina P, Serrano AL, Munoz-Canoves P. 2011. Aberrant repair and fibrosis development in skeletal muscle. Skelet Muscle 1: 21 .

Massague J, Cheifetz S, Endo T, Nadal-Ginard B. 1986. Type $\beta$ transforming growth factor is an inhibitor of myogenic differentiation. Proc Natl Acad Sci 83: 8206-8210.

Matthews VB, Astrom MB, Chan MH, Bruce CR, Krabbe KS, Prelovsek O, Akerstrom T, Yfanti C, Broholm C, Mortensen $\mathrm{OH}$, et al. 2009. Brain-derived neurotrophic factor is produced by skeletal muscle cells in response to contraction and enhances fat oxidation via activation of AMPactivated protein kinase. Diabetologia 52: 1409-1418.

Mauer J, Chaurasia B, Goldau J, Vogt MC, Ruud J, Nguyen KD, Theurich S, Hausen AC, Schmitz J, Bronneke HS, et al.
2014. Signaling by IL-6 promotes alternative activation of macrophages to limit endotoxemia and obesity-associated resistance to insulin. Nat Immunol 15: 423-430.

Maynard CL, Weaver CT. 2008. Diversity in the contribution of interleukin-10 to T-cell-mediated immune regulation. Immunol Rev 226: 219-233.

McKay BR, De Lisio M, Johnston AP, O’Reilly CE, Phillips SM, Tarnopolsky MA, Parise G. 2009. Association of interleukin-6 signalling with the muscle stem cell response following muscle-lengthening contractions in humans. PloS ONE 4: e6027.

McPherron AC, Lawler AM, Lee SJ. 1997. Regulation of skeletal muscle mass in mice by a new TGF- $\beta$ superfamily member. Nature 387: 83-90.

Mera P, Laue K, Ferron M, Confavreux C, Wei J, Galan-Diez M, Lacampagne A, Mitchell SJ, Mattison JA, Chen Y, et al. 2016. Osteocalcin signaling in myofibers is necessary and sufficient for optimum adaptation to exercise. Cell Metab 23: $1078-1092$.

Mikkelsen UR, Langberg H, Helmark IC, Skovgaard D, Andersen LL, Kjaer M, Mackey AL. 2009. Local NSAID infusion inhibits satellite cell proliferation in human skeletal muscle after eccentric exercise. J Appl Physiol (1985) 107: $1600-1611$.

Miyabe M, Ohashi K, Shibata R, Uemura Y, Ogura Y, Yuasa D, Kambara T, Kataoka Y, Yamamoto T, Matsuo K, et al. 2014. Muscle-derived follistatin-like 1 functions to reduce neointimal formation after vascular injury. Cardiovasc Res 103: $111-120$.

Moon HY, Becke A, Berron D, Becker B, Sah N, Benoni G, Janke E, Lubejko ST, Greig NH, Mattison JA, et al. 2016. Running-induced systemic cathepsin B secretion is associated with memory function. Cell Metab 24: 332-340.

Mooren FC, Lechtermann A, Fobker M, Brandt B, Sorg C, Volker K, Nacken W. 2006. The response of the novel proinflammatory molecules S100A8/A9 to exercise. Int J Sports Med 27: 751-758.

Mortensen OH, Andersen K, Fischer C, Nielsen AR, Nielsen S, Akerstrom T, Aastrom MB, Borup R, Pedersen BK. 2008. Calprotectin is released from human skeletal muscle tissue during exercise. J Physiol 586: 3551-3562.

Neubauer O, Sabapathy S, Ashton KJ, Desbrow B, Peake JM, Lazarus R, Wessner B, Cameron-Smith D, Wagner KH, Haseler LJ, et al. 2014. Time course-dependent changes in the transcriptome of human skeletal muscle during recovery from endurance exercise: From inflammation to adaptive remodeling. J Appl Physiol (1985) 116: 274-287.

Nielsen AR, Mounier R, Plomgaard P, Mortensen OH, Penkowa M, Speerschneider T, Pilegaard H, Pedersen BK. 2007. Expression of interleukin-15 in human skeletal muscle effect of exercise and muscle fibre type composition. J Physiol 584: 305-312.

Nielsen S, Scheele C, Yfanti C, Akerstrom T, Nielsen AR, Pedersen BK, Laye MJ. 2010. Muscle specific microRNAs are regulated by endurance exercise in human skeletal muscle. J Physiol 588: 4029-4037.

Nielsen S, Akerstrom T, Rinnov A, Yfanti C, Scheele C, Pedersen BK, Laye MJ. 2014. The miRNA plasma signature in response to acute aerobic exercise and endurance training. PloS ONE 9: e87308. 
Nieman DC, Henson DA, Smith LL, Utter AC, Vinci DM, Davis JM, Kaminsky DE, Shute M. 2001. Cytokine changes after a marathon race. J Appl Physiol (1985) 91: 109-114.

Nieman DC, Davis JM, Henson DA, Walberg-Rankin J, Shute M, Dumke CL, Utter AC, Vinci DM, Carson JA, Brown A, et al. 2003. Carbohydrate ingestion influences skeletal muscle cytokine mRNA and plasma cytokine levels after a 3-h run. J Appl Physiol (1985) 94: 1917-1925.

Nishimune H, Stanford JA, Mori Y. 2014. Role of exercise in maintaining the integrity of the neuromuscular junction. Muscle Nerve 49: 315-324.

Norheim F, Raastad T, Thiede B, Rustan AC, Drevon CA, Haugen F. 2011. Proteomic identification of secreted proteins from human skeletal muscle cells and expression in response to strength training. Am J Physiol Endocrinol Metab 301: E1013-E1021.

Olfert IM, Baum O, Hellsten Y, Egginton S. 2016. Advances and challenges in skeletal muscle angiogenesis. Am Physiol Heart Circ Physiol 310: H326-H336.

Oliveira M, Gleeson M. 2010. The influence of prolonged cycling on monocyte Toll-like receptor 2 and 4 expression in healthy men. Eur J Appl Physiol 109: 251-257.

Ost M, Coleman V, Kasch J, Klaus S. 2016. Regulation of myokine expression: Role of exercise and cellular stress. Free Radic Biol Med 98: 78-89.

Ostrowski K, Hermann C, Bangash A, Schjerling P, Nielsen JN, Pedersen BK. 1998a. A trauma-like elevation of plasma cytokines in humans in response to treadmill running. J Physiol 513: 889-894.

Ostrowski K, Rohde T, Zacho M, Asp S, Pedersen BK. 1998b. Evidence that interleukin-6 is produced in human skeletal muscle during prolonged running. J Physiol 508: 949-953.

Palsgaard J, Brons C, Friedrichsen M, Dominguez H, Jensen M, Storgaard H, Spohr C, Torp-Pedersen C, Borup R, De Meyts P, et al. 2009. Gene expression in skeletal muscle biopsies from people with type 2 diabetes and relatives: Differential regulation of insulin signaling pathways. PloS ONE 4: e6575.

Pataquiva-Mateus AY, Wu HC, Lucchesi C, Ferraz MP, Monteiro FJ, Spector M. 2012. Supplementation of collagen scaffolds with SPARC to facilitate mineralization. $J$ Biomed Mater Res B Appl Biomater 100: 862-870.

Paulsen G, Mikkelsen UR, Raastad T, Peake JM. 2012. Leucocytes, cytokines and satellite cells: What role do they play in muscle damage and regeneration following eccentric exercise? Exerc Immunol Rev 18: 42-97.

Peake JM, Suzuki K, Hordern M, Wilson G, Nosaka K, Coombes JS. 2005. Plasma cytokine changes in relation to exercise intensity and muscle damage. Eur J Appl Physiol 95: 514-521.

Pedersen BK, Febbraio MA. 2012. Muscles, exercise and obesity: Skeletal muscle as a secretory organ. Nat Rev Endocrinol 8: 457-465.

Pedersen BK, Saltin B. 2015. Exercise as medicine-Evidence for prescribing exercise as therapy in 26 different chronic diseases. Scand J Med Sci Sports 25: 1-72.

Pedersen BK, Steensberg A, Fischer C, Keller C, Keller P, Plomgaard P, Febbraio M, Saltin B. 2003. Searching for the exercise factor: Is IL-6 a candidate? J Muscle Res Cell Motil 24: 113-119.

Pedersen L, Idorn M, Olofsson GH, Lauenborg B, Nookaew I, Hansen RH, Johannesen HH, Becker JC, Pedersen KS, Dethlefsen C, et al. 2016. Voluntary running suppresses tumor growth through epinephrine- and IL-6-dependent NK cell mobilization and redistribution. Cell Metab 23: 554-562.

Perbal B. 2004. CCN proteins: Multifunctional signaling regulators. Lancet 363: 62-64.

Petersen EW, Carey AL, Sacchetti M, Steinberg GR, Macaulay SL, Febbraio MA, Pedersen BK. 2005. Acute IL-6 treatment increases fatty acid turnover in elderly humans in vivo and in tissue culture in vitro. Am J Physiol Endocrinol Metab 288: E155-E162.

Pierce JR, Maples JM, Hickner RC. 2015. IL-15 concentrations in skeletal muscle and subcutaneous adipose tissue in lean and obese humans: Local effects of IL-15 on adipose tissue lipolysis. Am J Physiol Endocrinol Metab 308: E1131-E1139.

Pillon NJ, Bilan PJ, Fink LN, Klip A. 2012. Crosstalk between skeletal muscle and immune cells: muscle-derived mediators and metabolic implications. Am J Physiol Endocrinol Metab 304: E453-E465.

Pistilli EE, Bogdanovich S, Garton F, Yang N, Gulbin JP, Conner JD, Anderson BG, Quinn LS, North K, Ahima RS, et al. 2011. Loss of IL-15 receptor $\alpha$ alters the endurance, fatigability, and metabolic characteristics of mouse fast skeletal muscles. J Clin Invest 121: 3120-3132.

Quinn LS, Anderson BG, Strait-Bodey L, Stroud AM, Argiles JM. 2009. Oversecretion of interleukin-15 from skeletal muscle reduces adiposity. Am J Physiol Endocrinol Metab 296: E191-E202.

Quinn LS, Anderson BG, Conner JD, Wolden-Hanson T. 2013. IL-15 overexpression promotes endurance, oxidative energy metabolism, and muscle PPARס, SIRT1, PGC- $1 \alpha$, and PGC-1 $\beta$ expression in male mice. Endocrinology 154: 232-245.

Rao RR, Long JZ, White JP, Svensson KJ, Lou J, Lokurkar I, Jedrychowski MP, Ruas JL, Wrann CD, Lo JC, et al. 2014. Meteorin-like is a hormone that regulates immune-adipose interactions to increase beige fat thermogenesis. Cell 157: 1279-1291.

Raschke S, Eckardt K, Bjorklund HK, Jensen J, Eckel J. 2013a. Identification and validation of novel contraction-regulated myokines released from primary human skeletal muscle cells. PloS ONE 8: e62008.

Raschke S, Elsen M, Gassenhuber H, Sommerfeld M, Schwahn U, Brockmann B, Jung R, Wisloff U, Tjonna AE, Raastad T, et al. 2013b. Evidence against a beneficial effect of irisin in humans. PloS ONE 8: e73680.

Revollo JR, Korner A, Mills KF, Satoh A, Wang T, Garten A, Dasgupta B, Sasaki Y, Wolberger C, Townsend RR, et al. 2007. Nampt/PBEF/Visfatin regulates insulin secretion in $\beta$ cells as a systemic NAD biosynthetic enzyme. Cell Metab 6: 363-375.

Riechman SE, Balasekaran G, Roth SM, Ferrell RE. 2004. Association of interleukin-15 protein and interleukin15 receptor genetic variation with resistance exercise training responses. J Appl Physiol (1985) 97: 2214-2219.

Rinnov A, Yfanti C, Nielsen S, Akerstrom TC, Peijs L, Zankari A, Fischer CP, Pedersen BK. 2014. Endurance train- 
ing enhances skeletal muscle interleukin-15 in human male subjects. Endocrine 45: 271-278.

Ristow M, Zarse K, Oberbach A, Kloting N, Birringer M, Kiehntopf M, Stumvoll M, Kahn CR, Bluher M. 2009. Antioxidants prevent health-promoting effects of physical exercise in humans. Proc Natl Acad Sci 106: $8665-$ 8670.

Roberts LD, Bostrom P, O'Sullivan JF, Schinzel RT, Lewis GD, Dejam A, Lee YK, Palma MJ, Calhoun S, Georgiadi $A$, et al. 2014. $\beta$-Aminoisobutyric acid induces browning of white fat and hepatic $\beta$-oxidation and is inversely correlated with cardiometabolic risk factors. Cell Metab 19: 96-108.

Rosendal L, Sogaard K, Kjaer M, Sjogaard G, Langberg H, Kristiansen J. 2005. Increase in interstitial interleukin-6 of human skeletal muscle with repetitive low-force exercise. J Appl Physiol (1985) 98: 477-481.

Ruderman NB, Keller C, Richard AM, Saha AK, Luo Z, Xiang X, Giralt M, Ritov VB, Menshikova EV, Kelley DE, et al. 2006. Interleukin-6 regulation of AMP-activated protein kinase: Potential role in the systemic response to exercise and prevention of the metabolic syndrome. Diabetes 55: S48-S54.

Rue N, Vissing J, Galbo H. 2014. Insulin resistance and increased muscle cytokine levels in patients with mitochondrial myopathy. J Clin Endocrinol Metab 99: 3757 3765.

Rullman E, Rundqvist H, Wagsater D, Fischer H, Eriksson P, Sundberg CJ, Jansson E, Gustafsson T. 2007. A single bout of exercise activates matrix metalloproteinase in human skeletal muscle. J Appl Physiol (1985) 102: 2346-2351.

Russell AP, Lamon S. 2015. Exercise, skeletal muscle and circulating microRNAs. Prog Mol Biol Transl Sci 135: 471-496.

Russell AP, Lamon S, Boon H, Wada S, Guller I, Brown EL, Chibalin AV, Zierath JR, Snow RJ, Stepto N, et al. 2013. Regulation of miRNAs in human skeletal muscle following acute endurance exercise and short-term endurance training. J Physiol 591: 4637-4653.

Safdar A, Saleem A, Tarnopolsky MA. 2016. The potential of endurance exercise-derived exosomes to treat metabolic diseases. Nat Rev Endocrinol 12: 504-517.

Saucedo Marquez CM, Vanaudenaerde B, Troosters T, Wenderoth N. 2015. High-intensity interval training evokes larger serum BDNF levels compared with intense continuous exercise. J Appl Physiol (1985) 119: 1363-1373.

Scheler M, Irmler M, Lehr S, Hartwig S, Staiger H, Al Hasani $\mathrm{H}$, Beckers J, de Angelis MH, Haring HU, Weigert C. 2013. Cytokine response of primary human myotubes in an in vitro exercise model. Am J Physiol Cell Physiol 305: C877-C886.

Schlittler M, Goiny M, Agudelo LZ, Venckunas T, Brazaitis M, Skurvydas A, Kamandulis S, Ruas JL, Erhardt S, Westerblad H, et al. 2016. Endurance exercise increases skeletal muscle kynurenine aminotransferases and plasma kynurenic acid in humans. Am J Physiol Cell Physiol 310: C836-C840

Schluns KS, Kieper WC, Jameson SC, Lefrancois L. 2000. Interleukin-7 mediates the homeostasis of I and memory CD8 T cells in vivo. Nat Immunol 1: 426-432.

Schoonjans K, Staels B, Auwerx J. 1996. Role of the peroxisome proliferator-activated receptor (PPAR) in mediat- ing the effects of fibrates and fatty acids on gene expression. J Lipid Res 37: 907-925.

Schuelke M, Wagner KR, Stolz LE, Hubner C, Riebel T, Komen W, Braun T, Tobin JF, Lee SJ. 2004. Myostatin mutation associated with gross muscle hypertrophy in a child. N Engl J Med 350: 2682-2688.

Seldin MM, Peterson JM, Byerly MS, Wei Z, Wong GW. 2012. Myonectin (CTRP15), a novel myokine that links skeletal muscle to systemic lipid homeostasis. J Biol Chem 287: $11968-11980$.

Serrano AL, Baeza-Raja B, Perdiguero E, Jardi M, MunozCanoves P. 2008. Interleukin-6 is an essential regulator of satellite cell-mediated skeletal muscle hypertrophy. Cell Metab 7: 33-44.

Smith LL, Anwar A, Fragen M, Rananto C, Johnson R, Holbert D. 2000. Cytokines and cell adhesion molecules associated with high-intensity eccentric exercise. Eur J Appl Physiol 82: 61-67.

Staiger H, Haas C, Machann J, Werner R, Weisser M, Schick F, Machicao F, Stefan N, Fritsche A, Haring HU. 2009. Muscle-derived angiopoietin-like protein 4 is induced by fatty acids via peroxisome proliferator-activated receptor (PPAR) $\delta$ and is of metabolic relevance in humans. Diabetes 58: $579-589$.

Starkie RL, Arkinstall MJ, Koukoulas I, Hawley JA, Febbraio MA. 2001. Carbohydrate ingestion attenuates the increase in plasma interleukin-6, but not skeletal muscle interleukin-6 mRNA, during exercise in humans. J Physiol 533: 585-591.

Steensberg A, van Hall G, Osada T, Sacchetti M, Saltin B, Klarlund PB. 2000. Production of interleukin-6 in contracting human skeletal muscles can account for the exercise-induced increase in plasma interleukin-6. J Physiol 529: $237-242$.

Steensberg A, Febbraio MA, Osada T, Schjerling P, van Hall G, Saltin B, Pedersen BK. 2001. Interleukin-6 production in contracting human skeletal muscle is influenced by preexercise muscle glycogen content. J Physiol 537: 633-639.

Steensberg A, Keller C, Starkie RL, Osada T, Febbraio MA, Pedersen BK. 2002. IL-6 and TNF- $\alpha$ expression in, and release from, contracting human skeletal muscle. Am J Physiol Endocrinol Metab 283: E1272-E1278.

Steensberg A, Fischer CP, Keller C, Moller K, Pedersen BK. 2003. IL-6 enhances plasma IL-1ra, IL-10, and cortisol in humans. Am J Physiol Endocrinol Metab 285: E433-E437.

Stewart LK, Flynn MG, Campbell WW, Craig BA, Robinson JP, McFarlin BK, Timmerman KL, Coen PM, Felker J, Talbert E. 2005. Influence of exercise training and age on $\mathrm{CD} 14^{+}$cell-surface expression of toll-like receptor 2 and 4. Brain Behav Immun 19: 389-397.

Strobel NA, Peake JM, Matsumoto A, Marsh SA, Coombes JS, Wadley GD. 2011. Antioxidant supplementation reduces skeletal muscle mitochondrial biogenesis. Med Sci Sports Exerc 43: 1017-1024.

Stromberg A, Olsson K, Dijksterhuis JP, Rullman E, Schulte G, Gustafsson T. 2016. CX3CL1-A macrophage chemoattractant induced by a single bout of exercise in human skeletal muscle. Am J Physiol Regul Integr Comp Physiol 310: R297-R304.

Subbotina E, Sierra A, Zhu Z, Gao Z, Koganti SR, Reyes S, Stepniak E, Walsh SA, Acevedo MR, Perez-Terzic CM, et al. 2015. Musclin is an activity-stimulated myokine that 
enhances physical endurance. Proc Natl Acad Sci 112: 16042-16047.

Suzuki K, Peake J, Nosaka K, Okutsu M, Abbiss CR, Surriano R, Bishop D, Quod MJ, Lee $\mathrm{H}$, Martin DT, et al. 2006. Changes in markers of muscle damage, inflammation and HSP70 after an Ironman Triathlon race. Eur J Appl Physiol 98: 525-534.

Tamura Y, Watanabe K, Kantani T, Hayashi J, Ishida N, Kaneki M. 2011. Upregulation of circulating IL-15 by treadmill running in healthy individuals: Is IL-15 an endocrine mediator of the beneficial effects of endurance exercise? Endocr J 58: 211-215.

Tantiwong P, Shanmugasundaram K, Monroy A, Ghosh S, Li M, DeFronzo RA, Cersosimo E, Sriwijitkamol A, Mohan S, Musi N. 2010. NF- $\kappa B$ activity in muscle from obese and type 2 diabetic subjects under basal and exercise-stimulated conditions. Am J Physiol Endocrinol Metab 299: E794-E801.

Tiano JP, Springer DA, Rane SG. 2015. SMAD3 negatively regulates serum irisin and skeletal muscle FNDC5 and peroxisome proliferator-activated receptor $\gamma$ coactivator 1- $\alpha$ (PGC-1 $\alpha$ ) during exercise. J Biol Chem 290: $7671-$ 7684.

Timmerman KL, Flynn MG, Coen PM, Markofski MM, Pence BD. 2008. Exercise training-induced lowering of inflammatory $\left(\mathrm{CD} 14^{+} \mathrm{CD} 16^{+}\right)$monocytes: A role in the anti-inflammatory influence of exercise? J Leukoc Biol 84: 1271-1278.

Toft AD, Falahati A, Steensberg A. 2011. Source and kinetics of interleukin-6 in humans during exercise demonstrated by a minimally invasive model. Eur J Appl Physiol 111: 1351-1359.

Toth KG, McKay BR, De Lisio M, Little JP, Tarnopolsky MA, Parise G. 2011. IL-6 induced STAT3 signalling is associated with the proliferation of human muscle satellite cells following acute muscle damage. PLoS ONE 6: e17392.

Trappe TA, White F, Lambert CP, Cesar D, Hellerstein M, Evans WJ. 2002. Effect of ibuprofen and acetaminophen on postexercise muscle protein synthesis. Am J Physiol Endocrinol Metab 282: E551-E556.

Trappe TA, Carroll CC, Dickinson JM, LeMoine JK, Haus JM, Sullivan BE, Lee JD, Jemiolo B, Weinheimer EM, Hollon CJ. 2011. Influence of acetaminophen and ibuprofen on skeletal muscle adaptations to resistance exercise in older adults. Am J Physiol Regul Integr Comp Physiol 300: R655-R662.

Turner CH. 2006. Bone strength: Current concepts. Ann NY Acad Sci 1068: 429-446.

Urso ML. 2013. Anti-inflammatory interventions and skeletal muscle injury: Benefit or detriment? J Appl Physiol (1985) 115: 920-928.

van Hall G, Steensberg A, Sacchetti M, Fischer C, Keller C, Schjerling P, Hiscock N, Moller K, Saltin B, Febbraio MA, et al. 2003. Interleukin-6 stimulates lipolysis and fat oxidation in humans. J Clin Endocrinol Metab 88: 30053010.

Velloso CP. 2008. Regulation of muscle mass by growth hormone and IGF-I. Br J Pharmacol 154: 557-568.

Wahl P, Zinner C, Achtzehn S, Behringer M, Bloch W, Mester J. 2011. Effects of acid-base balance and high or low intensity exercise on VEGF and bFGF. Eur J Appl Physiol 111: $1405-1413$.
Walker KS, Kambadur R, Sharma M, Smith HK. 2004. Resistance training alters plasma myostatin but not IGF- 1 in healthy men. Med Sci Sports Exerc 36: 787-793.

Watt MJ, Dzamko N, Thomas WG, Rose-John S, Ernst M, Carling D, Kemp BE, Febbraio MA, Steinberg GR. 2006. CNTF reverses obesity-induced insulin resistance by activating skeletal muscle AMPK. Nat Med 12: 541-548.

Weigert C, Hennige AM, Lehmann R, Brodbeck K, Baumgartner F, Schauble M, Haring HU, Schleicher ED. 2006. Direct cross-talk of interleukin-6 and insulin signal transduction via insulin receptor substrate-1 in skeletal muscle cells. J Biol Chem 281: 7060-7067.

Weigert C, Lehmann R, Hartwig S, Lehr S. 2014. The secretome of the working human skeletal muscle-A promising opportunity to combat the metabolic disaster? Proteomics Clin Appl 8: 5-18.

WHO. 2010. Global recommendations on physical activity for health. WHO Press, Geneva.

Wilkes JJ, Lloyd DJ, Gekakis N. 2009. Loss-of-function mutation in myostatin reduces tumor necrosis factor $\alpha$ production and protects liver against obesity-induced insulin resistance. Diabetes 58: 1133-1143.

Williams AS, Kang L, Wasserman DH. 2015. The extracellular matrix and insulin resistance. Trends Endocrinol Metab 26: 357-366.

Wrann CD, White JP, Salogiannnis J, Laznik-Bogoslavski D, Wu J, Ma D, Lin JD, Greenberg ME, Spiegelman BM. 2013. Exercise induces hippocampal BDNF through a PGC-1 $\alpha$ /FNDC5 pathway. Cell Metab 18: 649-659.

Xu G, Hansen JS, Zhao XJ, Chen S, Hoene M, Wang XL, Clemmesen JO, Secher NH, Haring HU, Pedersen BK, et al. 2016. Liver and muscle contribute differently to the plasma acylcarnitine pool during fasting and exercise in humans. J Clin Endocrinol Metab 101: 5044-5052.

Yadav H, Quijano C, Kamaraju AK, Gavrilova O, Malek R, Chen W, Zerfas P, Zhigang D, Wright EC, Stuelten C, et al. 2011. Protection from obesity and diabetes by blockade of TGF- $\beta /$ Smad3 signaling. Cell Metab 14: 67-79.

Yamamoto T, Habata Y, Matsumoto Y, Yasuhara Y, Hashimoto T, Hamajyo H, Anayama H, Fujii R, Fuse H, Shintani Y, et al. 2011. Apelin-transgenic mice exhibit a resistance against diet-induced obesity by increasing vascular mass and mitochondrial biogenesis in skeletal muscle. Biochim Biophys Acta 1810: 853-862.

Yeh SH, Chuang H, Lin LW, Hsiao CY, Eng HL. 2006. Regular tai chi chuan exercise enhances functional mobility and CD4CD25 regulatory T cells. Br J Sports Med 40: 239-243.

Zamurs LK, Idoate MA, Hanssen E, Gomez-Ibanez A, Pastor P, Lamande SR. 2015. Aberrant mitochondria in a Bethlem myopathy patient with a homozygous amino acid substitution that destabilizes the collagen VI $\alpha 2$ (VI) chain. J Biol Chem 290: 4272-4281.

Zeng L, Akasaki Y, Sato K, Ouchi N, Izumiya Y, Walsh K. 2010. Insulin-like 6 is induced by muscle injury and functions as a regenerative factor. J Biol Chem 285: 3606036069.

Zhao B, Wall RJ, Yang J. 2005. Transgenic expression of myostatin propeptide prevents diet-induced obesity and insulin resistance. Biochem Biophys Res Commun 337: $248-255$. 


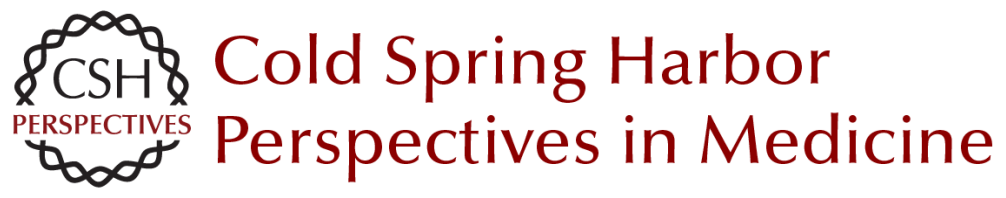

\title{
Skeletal Muscle as an Endocrine Organ: The Role of Myokines in Exercise Adaptations
}

\author{
Christoph Hoffmann and Cora Weigert
}

Cold Spring Harb Perspect Med 2017; doi: 10.1101/cshperspect.a029793 originally published online April 7, 2017

\section{Subject Collection The Biology of Exercise}

Exosomes as Mediators of the Systemic

Adaptations to Endurance Exercise Adeel Safdar and Mark A. Tarnopolsky

Molecular Basis of Exercise-Induced Skeletal

Muscle Mitochondrial Biogenesis: Historical

Advances, Current Knowledge, and Future

Challenges

Christopher G.R. Perry and John A. Hawley

Exercise Metabolism: Fuels for the Fire

Mark Hargreaves and Lawrence L. Spriet

Health Benefits of Exercise

Gregory N. Ruegsegger and Frank W. Booth

Molecular Regulation of Exercise-Induced Muscle

Fiber Hypertrophy

Marcas M. Bamman, Brandon M. Roberts and

Gregory R. Adams

Physiological Redundancy and the Integrative

Responses to Exercise

Michael J. Joyner and Jerome A. Dempsey

On the Run for Hippocampal Plasticity

C'iana Cooper, Hyo Youl Moon and Henriette van

Praag

Molecular Basis for Exercise-Induced Fatigue:

The Importance of Strictly Controlled Cellular Ca

2+ Handling

Arthur J. Cheng, Nicolas Place and Håkan

Westerblad
Effects of Exercise and Aging on Skeletal Muscle Giovanna Distefano and Bret $H$. Goodpaster

Muscle-Adipose Tissue Cross Talk Kristin I. Stanford and Laurie J. Goodyear

Performance Fatigability: Mechanisms and Task Specificity Sandra K. Hunter

Adaptations to Endurance and Strength Training David C. Hughes, Stian Ellefsen and Keith Baar

The Bioenergetics of Exercise $P$. Darrell Neufer

Effects of Exercise on Vascular Function, Structure, and Health in Humans Daniel J. Green and Kurt J. Smith

Control of Muscle Metabolism by the Mediator Complex Leonela Amoasii, Eric N. Olson and Rhonda Bassel-Duby

Theoretical and Biological Evaluation of the Link between Low Exercise Capacity and Disease Risk Lauren Gerard Koch and Steven L. Britton

For additional articles in this collection, see http://perspectivesinmedicine.cshlp.org/cgi/collection/ 